
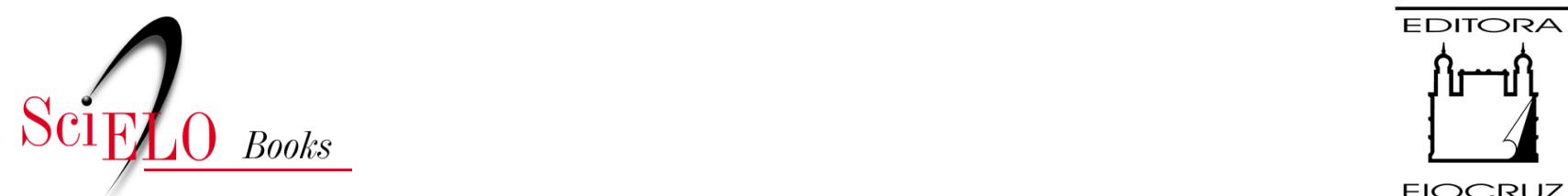

FIOCRUZ

\title{
5. Complexo econômico-industrial da saúde, segurança e autonomia estratégica a inserção do Brasil no mundo
}

\author{
Raphael Padula \\ Gustavo Souto de Noronha \\ Thiago Leone Mitidieri
}

\section{SciELO Books / SciELO Livros / SciELO Libros}

PADULA, R., NORONHA, G.S., and MITIDIERI, T.L. Complexo econômico-industrial da saúde, segurança e autonomia estratégica: a inserção do Brasil no mundo. In: GADELHA, C.A.G., GADELHA, P., NORONHA, J.C., and PEREIRA, T.R., eds. Brasil Saúde Amanhã: complexo econômico-industrial da saúde [online]. Rio de Janeiro: Editora FIOCRUZ, 2017, pp. 173-227. ISBN: 978-65-5708-092-4. https://doi.org/10.7476/9786557080924.0007.

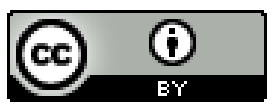

All the contents of this work, except where otherwise noted, is licensed under a Creative Commons Attribution 4.0 International license.

Todo o conteúdo deste trabalho, exceto quando houver ressalva, é publicado sob a licença Creative Commons Atribição 4.0.

Todo el contenido de esta obra, excepto donde se indique lo contrario, está bajo licencia de la licencia $\underline{\text { Creative }}$ Commons Reconocimento 4.0. 


\title{
COMPLEXO ECONÔMICO-INDUSTRIAL DA SAÚDE, SEGURANÇA E AUTONOMIA ESTRATÉGICA: A INSERÇÃO DO BRASIL NO MUNDO
}

\author{
Raphael Padula \\ Gustavo Souto de Noronha \\ Thiago Leone Mitidieri"
}

A genoterapia continuou a ser aprimorada velozmente. Mas, por ser um procedimento extremamente caro, só estava ao alcance de famílias bastante ricas, de países ricos e estáveis que nela podiam investir. (...)

As pessoas beneficiadas pela nova terapia foram chamadas de genos e, em pouco tempo, seu número cresceu o suficiente para que os laboratórios pudessem passar a viver exclusivamente da genoterapia. Os lucros se tornaram de tal modo elevados que os laboratórios deixaram de fabricar os medicamentos convencionais, responsáveis por uma relação custo-benefício insignificante.

Alguns governos de países desenvolvidos, e outros do mundo em desenvolvimento, tentaram obrigar os laboratórios a seguir fabricando medicamentos convencionais, capazes de atender os que não podiam pagar pela nova terapia. Mas esses governos foram derrubados por processos de impeachment, mecanismo previsto em suas Constituições e votado por Parlamentos democráticos. Ou foram eliminados por revoluções sangrentas, feitas em nome da liberdade, do livre-arbítrio e do direito de escolha.

Apesar da decadência da medicina convencional, a parcela grandemente majoritária da população de países ricos e estáveis que não tinha condições financeiras para se beneficiar da genoterapia continuou a crescer, embora a elevação estatística dos óbitos infantis causasse preocupação. Esses não genos, cumprindo o dever de proteger a saúde de suas famílias, se organizaram para evitar a exportação do que havia restado de médicos e de medicamentos convencionais.

Essa política protecionista provocou guerras localizadas, e focos de conflitos regionais explodiram pelo mundo afora. Os genos não se envolveram, limitando-se a agir por motivos humanitários e, sempre que necessário, procuraram evitar graves prejuízos ao meio ambiente, ao planeta e à civilização, impedindo o uso de armas químicas e nucleares de destruição em massa. Graças a essas intervenções, aprovadas pelos organismos internacionais, as consequências desastrosas das guerras ficaram restritas aos combatentes e suas regiões. Os "lucros com esta se tornaram de tal modo elevados que os laboratórios deixaram de fabricar os medicamentos convencionais" para os homens comuns. (...)

Logo os genos sofreram uma mutação genética, tornando-se uma nova espécie, dentro do gênero humano. Lembrando a origem fundadora de sua evolução, antropólogos e biólogos convencionaram chamar a nova espécie de Homo ricus.

Carlos Diegues, “Seleção artificial”, 2008

* As opiniões do autor não refletem a opinião do BNDES. 
O trecho em epígrafe foi extraído de artigo publicado pela revista Piauí em que o cineasta Carlos Diegues vislumbra o surgimento, no futuro, do Homo ricus, desenvolvido como uma evolução artificial do Homo sapiens a partir de uma parcela da população com acesso a serviços de terapia genética na fronteira tecnológica dissociada dos demais humanos. Nessa análise ficcional, o autor delineia um futuro em que a divisão da sociedade em classes sociais pode se transformar numa divisão em espécies. Diante das disputas geoeconômicas e geopolíticas internacionais, os avanços e inovações que têm se desenvolvido na genética, na biotecnologia, na nanotecnologia, na química, na neurociência e em outros campos de ponta na pesquisa biomédica, não se pode descartar de todo a ficção de Diegues, que talvez apresente contornos mais vinculados às relações de poder global, e não apenas a aspectos econômicos.

Nosso primeiro objetivo aqui é realizar uma reflexão sobre o conceito de complexo econômicoindustrial da saúde (CEIS) formulado por Carlos Gadelha (Gadelha \& Costa, 2013a), propondo sua ampliação tendo em vista a economia política internacional. Para isso, recorreremos aos conceitos de autonomia estratégica e segurança em saúde em uma perspectiva nacional, inserindo uma visão político-estratégica, apoiada na perspectiva geopolítica e realista das relações internacionais, condizente com a abordagem do poder global de José Luís Fiori (2013). O segundo objetivo é olhar para o Brasil e o CEIS, e suas tendências para os próximos 15 anos, tomando como base os conceitos de autonomia estratégica e de segurança em saúde.

Na primeira seção deste texto empreendemos uma análise da concepção do CEIS considerando três aspectos: o conceito de autonomia estratégica; a importância da segurança nacional, e mais especificamente da segurança em saúde e suas conexões com o CEIS; as relações entre Estados e tecnologias estratégicas, e as sinergias entre saúde e complexo industrial-militar.

Na segunda parte delineamos um panorama e as macrotendências globais do jogo entre as grandes potências e as chamadas potências emergentes, a aceleração da competição interestatal, os grandes acordos bilaterais, regionais e multilaterais - envolvendo acesso a mercados, compras governamentais, investimentos e propriedade intelectual. Trataremos do papel do Brasil no sistema internacional, seus potenciais conflitos de interesses estratégicos (não necessariamente bélicos) em torno do tema da saúde, na procura pela autonomia estratégica brasileira, associada à política nacional de defesa e à oportunidade de formação de clusters produtivos e científico-tecnológicos com o CEIS.

Na terceira seção concentraremos a análise no panorama nacional, com ênfase no papel do Estado no concernente à dinâmica de mercado e da inovação tecnológica na universalização do acesso à saúde com equidade. Observaremos a vulnerabilidade externa nos campos produtivo, comercial, tecnológico e político-estratégico, em diferentes segmentos do CEIS.

Na quarta seção trataremos das macrotendências para os próximos vinte anos - nos quais o Brasil e seu entorno estratégico estarão inevitavelmente inseridos na crescente disputa por mercados e recursos, envolvendo potências tradicionais e emergentes - que terão impactos sobre a indústria de saúde. 


\section{Questões Preambulares e Revisão Conceitual: o CEIS, a autonomia e a segurança estratégica}

Nunca é alto o preço a pagar pelo privilégio de pertencer a si mesmo.

Friedrich Nietzsche

Esta seção é dedicada à concepção de complexo econômico-industrial da saúde (CEIS), considerada com base em três aspectos: o conceito de autonomia estratégica e a importância do CEIS quando se trata de conquistá-la; a importância da segurança nacional, e mais especificamente da segurança em saúde, e suas conexões com o CEIS e a autonomia estratégica; as relações entre Estados e tecnologias estratégicas, destacando as conexões entre a área de saúde e a indústria militar, com menção às experiências de potências tradicionais (Estados Unidos) e emergentes (China). Ademais, apontamos nesta seção questões preambulares, muitas das quais não serão tratadas aqui por questões de espaço e escopo, mas podem servir para uma agenda de pesquisa futura.

\section{CEIS e autonomia estratégica}

Como destacam Gadelha e Costa (2013a), a análise do CEIS ${ }^{1}$ se debruça sobre a relação sistêmica estabelecida entre segmentos industriais e o setor de serviços de saúde e, consequentemente, sobre sua construção sistêmica no âmbito de uma economia nacional. Ademais, as análises de crescimento econômico, mudanças na estrutura produtiva e melhoria do padrão de vida da população em uma economia nacional devem colocar em evidência a importância do CEIS. A análise do CEIS coadunase com a utilização do arcabouço teórico-conceitual da economia política da saúde, que coloca em relevo as tensões relativas aos interesses sociais diante dos econômicos envolvidos, politizando o debate e evidenciando a necessidade de atuação do Estado na construção de seu arcabouço legal-institucional. Tal perspectiva retoma e atualiza a abordagem estruturalista, "que privilegia os fatores histórico-estruturais característicos da sociedade brasileira", passando pela sua "inserção internacional, assim como sua relação com uma difusão extremamente assimétrica do progresso técnico e, nos termos atuais, do conhecimento e do aprendizado, dissociados das necessidades locais" (Gadelha \& Costa, 2013a:109).

Tal abordagem enfatiza questões fundamentais como o caráter estratégico do CEIS e da universalização do acesso à saúde do ponto de vista econômico e social, e ressalta potenciais conflitos decorrentes dessa lógica, na dimensão política interna - principalmente entre empresas e Estado - e na arena internacional - no concernente à atuação das empresas transnacionais ou às relações econômicas (comerciais, financeiras e acerca de direitos de propriedade intelectual) entre Estados. Em acordo com essa visão, apresentamos uma concepção político-estratégica mais ampla na agenda de saúde, concernente às relações interestatais, com base no arcabouço teórico da economia política internacional (EPI), na qual os conflitos não resultam somente de interesses econômicos, mas também

1 "Gadelha e colaboradores (2012) caracterizam este complexo a partir de uma segmentação em indústrias de base química e biotecnológica (farmacêutica, vacinas, hemoderivados e reagentes para diagnóstico); indústrias de base mecânica, eletrônica e de materiais (equipamentos e materiais médico-hospitalares e odontológicos); e serviços de saúde (produção hospitalar, laboratorial e de serviços de diagnóstico e tratamento)" (Gadelha \& Costa, 2013a: 109). 
de interesses eminentemente político-estratégicos presentes nas relações de poder. Uma abordagem geopolítica e realista das relações internacionais, condizente com a concepção do poder global de José Luís Fiori (2013).

A análise do sistema interestatal capitalista parte de sua natureza anárquica: os Estados são os principais atores do sistema (não há nenhuma unidade política superior a eles) e, para cumprir suas funções básicas de prover segurança e desenvolvimento para suas sociedades, atuam de forma autointeressada na busca pelo acúmulo relativo de poder e riqueza frente a outros Estados. Assim, o sistema é dinâmico e caracterizado pela sua pressão competitiva permanente. Os Estados têm diferentes graus de poder e riqueza, mas tal hierarquia não elimina a competição entre as grandes potências: os que estão em posições privilegiadas tentam manter o status quo e os que estão em posições inferiores tentam mudar sua condição. Há uma diversidade de atores atuando no sistema internacional, em diferentes escalas político-geográficas. No entanto, os Estados, como atores formalmente independentes e soberanos, detêm o monopólio da coerção e da legislação dentro de suas fronteiras nacionais, ao passo que no sistema internacional são os atores que constroem as regras do jogo, o arcabouço jurídico-institucional com base no qual atuam os demais atores e os próprios Estados - uma moldura que reflete as relações de poder interestatais.

Assim, nessa abordagem, riqueza e poder não devem ser vistos em separado, em um sistema de Estados que perseguem seu interesse próprio (não atuam de forma cosmopolita). O acúmulo de poder e riqueza atua de forma coadunada e sinérgica: um Estado rico e sem poder é encarado como débil e vulnerável diante dos interesses e ações de potências externas. E o aumento de poder seria fundamental não só para a segurança da riqueza, mas também como um meio para ampliá-la. Portanto, os Estados tentam construir molduras jurídico-institucionais no sistema internacional que sejam favoráveis à atuação e expansão de suas grandes empresas transnacionais e de seu capital financeiro, visando a acumular capital, mas ao mesmo tempo maior poder relativo. Estados fortes atuam de acordo com os interesses das suas empresas e da manutenção de assimetrias estruturais no sistema internacional, promovendo acordos e usando sua influência em organizações internacionais como forma de legitimar seus interesses, construindo regras e regimes internacionais que lhes sejam favoráveis. $^{2}$

É com base nesse arcabouço teórico que analisamos a agenda de saúde. Consideramos que a indústria de saúde tem papel fundamental no desenvolvimento sistêmico, tecnológico e socioeconômico de uma economia nacional, assim como na universalização do acesso à saúde com equidade e desconcentração geográfica pelo território nacional. Além disso, buscamos inserir tais questões e objetivos em um contexto mais amplo, na perseguição da autonomia estratégica e da segurança nacional, de forma coadunada com a questão do desenvolvimento socioeconômico e da universalização do atendimento em saúde.

2 Para Krasner (2009: 13), "regimes internacionais são definidos como princípios, normas, regras e procedimentos de tomada de decisão, sobre os quais as expectativas dos atores convergem em uma determinada área temática". Princípios são formados por um conjunto coerente de afirmações teóricas sobre como o mundo funciona. Normas especificam padrões gerais de comportamento. Princípios e normas definem a característica básica de qualquer regime. 
A análise sobre o CEIS, e suas possibilidades de desenvolvimento e inovação tecnológica deve partir da centralidade da autonomia estratégica como objetivo político de um Estado em relação ao sistema internacional. A concepção de autonomia estratégica tem caráter político e vai além da concepção jurídica internacional de soberania (entendida como o mútuo reconhecimento e igualdade jurídica dos Estados, que antecede a prática de autonomia). Autonomia estratégica refere-se ao grau de liberdade política de um Estado de tomar decisões para, tanto no âmbito da política interna quanto na sua política externa, perseguir e construir regras favoráveis ao seu desenvolvimento socioeconômico e à sua segurança diante dos interesses, ações e vontades de atores externos no sistema internacional - que muitas vezes se articulam com interesses de grupos políticos internos. Nesse sentido, a autonomia estratégica pode lembrar a busca pela autarquia econômica (não como um modelo ideal inalcançável, mas como uma direção a ser perseguida), que deve ser relativizada como a autonomia estratégica na produção de bens estratégicos, considerando ainda a importância do comércio exterior (exportações) para que países não emissores da moeda de curso internacional tenham acesso a divisas internacionais. A ideia de que a autonomia estratégica está relacionada com a industrialização como política de Estado esteve presente em autores de economia política, usualmente referidos na literatura sobre história do pensamento econômico como industrialistas ou nacionalistas econômicos, como Alexander Hamilton e Friedrich List. ${ }^{3}$ Mais propriamente, esses autores viam o processo de industrialização não só como o motor do progresso econômico, mas como uma forma de internalizar a produção dos bens estratégicos como um meio para alcançar maior independência (liberdade) política no sistema internacional, ou reduzir as vulnerabilidades externas nos campos econômico e político. Segundo Gilpin (2001), a procura pela autonomia nacional envolve a inevitável colisão entre a lógica do mercado e a lógica do Estado. ${ }^{4}$ No entanto, do nosso ponto de vista, envolve também conflitos de interesses interestatais. Conforme Krasner (1985), embora sejam fracos politicamente nas suas dimensões interna e externa, os Estados subdesenvolvidos ${ }^{5}$ querem mais do que riqueza: querem mais poder e mais controle em relação a vulnerabilidades e ameaças, por meio de estratégias de reformistas (mudando regras e os regimes internacionais), o que é incompatível

\footnotetext{
${ }^{3}$ A leitura atenta das obras Relatório sobre as Manufaturas, de 1791, e Sistema Nacional de Economia Política, de 1841, respectivamente de Alexander Hamilton, um dos fundadores e primeiro secretário de Tesouro dos Estados Unidos, e de Friedrich List, promotor do Zollverein, a união aduaneira alemã, permite compreender que a concepção industrialista-nacionalista, na direção da autonomia estratégica, vai muito além de uma análise meramente econômica. No plano mais geral, esses autores têm uma visão clara de que riqueza e poder não devem ser encarados de forma separada em um sistema de Estados autointeressados que perseguem seu interesse próprio (não atuam de forma cosmopolita). Um Estado deve acumular poder e riqueza de forma coadunada e sinérgica, pois um Estado rico e sem poder é considerado débil e vulnerável diante dos interesses e ações de potências externas, como já previa Maquiavel. E o aumento de poder seria fundamental para a segurança da riqueza e também um meio para ampliá-la, e vice-versa.

4 "Um dos temas dominantes no estudo da economia política internacional (EPI) é o persistente conflito entre a crescente interdependência da economia internacional e o desejo de Estados individuais de manterem sua independência econômica e autonomia política. Ao mesmo tempo que os Estados querem os benefícios da liberalização do comércio, investimento estrangeiro e equivalentes, eles também desejam proteger sua autonomia política, valores culturais, e estruturas sociais. (...) Ao passo que a lógica do mercado é alocar atividades econômicas onde elas forem mais eficientes e lucrativas, a lógica do Estado é capturar e controlar o processo de crescimento econômico e acumulação de capital com o objetivo de aumentar o poder e o bem-estar econômico da nação" (Gilpin, 2001: 81, tradução nossa).

${ }^{5}$ Na época, Krasner (1985) utiliza o termo corrente Terceiro Mundo para se referir aos Estados subdesenvolvidos.
} 
com os interesses a longo prazo das grandes potências do hemisfério norte. Assim, da distribuição de poder assimétrica do sistema interestatal emergem conflitos estruturais. Em outras palavras, caso queiram alterar sua condição de vulnerabilidade e dependência, os Estados subdesenvolvidos não podem deixar de desafiar princípios, normas e regras que são de interesse das potências do norte e de suas grandes corporações.

Os bens estratégicos seriam aqueles fundamentais para a segurança estratégica e o funcionamento, bem-estar econômico e desenvolvimento de uma nação (de sua sociedade e economia), incluindo os setores industriais com maiores efeitos de encadeamento produtivo e de transbordamento de tecnologia para outros setores da economia, que sejam intensivos em avanços tecnológicos de ponta e para a defesa nacional. Mesmo que a produção interna envolva temporariamente um custo contábil-econômico superior, a autonomia estratégica seria compensada pelos ganhos da independência política, ou redução da dependência econômica e política externa. A dependência das relações exteriores e da lógica do mercado (a interdependência tão badalada pela ideologia da globalização) é essencialmente assimétrica, de forma desfavorável aos países periféricos, representando uma fonte de vulnerabilidade, visto que conflitos e decisões políticas externas (de outros Estados e empresas e investidores privados) poderiam prejudicar ou interromper fluxos comerciais, financeiros e tecnológicos, causando danos à segurança e ao bem-estar econômico. Mais que isso, pode ensejar o poder de veto e a projeção de poder e influência de potências externas em decisões de política interna e externa. A visão defendida aqui difere da (neo)schumpeteriana ou estruturalista latino-americana (ou cepalina clássica), segundo a qual o avanço tecnológico depende unicamente das decisões do empresário e/ou das políticas adotadas por um Estado em relação à sua economia "para dentro" (o que afetaria inclusive a atuação de empresas transnacionais). Na abordagem aqui apresentada, além dessas decisões, ganham relevo as relações interestatais - as pressões exercidas e os acordos firmados - na criação, difusão e/ou concentração de avanços tecnológicos, com destaque para a relação virtuosa entre o desenvolvimento da indústria militar e os avanços produtivos e científico-tecnológicos.

Argumentamos aqui que o CEIS é uma indústria fundamental para a autonomia estratégica do Brasil. O CEIS tem importante peso no produto interno bruto (PIB), é intensivo em tecnologias de ponta (portadoras de futuro), que se espalham ou se conectam com outros setores (de caráter transversal), especialmente a indústria militar - principalmente se considerados a biotecnologia e a nanotecnologia e o setor de equipamentos e materiais de saúde -, e a oferta/demanda dos bens e serviços de saúde é essencial para o funcionamento e o desenvolvimento da economia e da sociedade. Por isso, a indústria de saúde é considerada estratégica nos Estados fortes e influentes do sistema internacional, e tem sido tratada da mesma forma nos projetos nacionais de potências emergentes, como a China e a Índia.

\section{Segurança em saúde, segurança nacional e autonomia estratégica}

As funções básicas de um Estado são prover segurança e desenvolvimento para sua sociedade, tão essenciais que este não pode delegá-las ou submetê-las à vontade e às ações de terceiros. Sem segurança não pode haver desenvolvimento em uma sociedade, e sem desenvolvimento não pode 
haver segurança. A indústria de saúde tem papel central na segurança e no desenvolvimento de uma nação. E mesmo países tradicionalmente pacíficos como o Brasil precisam se preocupar com sua segurança (no sentido dissuasivo) diante de possíveis ameaças e de interesses externos. Isso é fundamental para sua liberdade política e capacidade de dizer não quando lhe for conveniente.

No período pós-Guerra Fria, a evolução dos estudos estratégicos, e especificamente da segurança internacional, ampliou a agenda de segurança para além da questão militar; procurou-se reestruturar o discurso da segurança com base na noção de "ameaças" que partem de outras áreas, e não somente da agressão militar de um Estado contra outro. Na evolução da agenda de estudos de segurança, ganha destaque Barry Buzan como autor proeminente sobre o tema. Para ele, no século XXI, a agenda de segurança, além da segurança militar, deveria se ampliar para abranger temas como segurança política, segurança econômica, segurança societária e segurança ambiental - temas de segurança (security issues) que teriam interconexões. ${ }^{6}$ Segundo Buzan (1991), a segurança militar compreende a capacidade ofensiva e a capacidade defensiva e dissuasória das Forças Armadas, assim como as percepções do Estado sobre as intenções de outros atores e seus poderes, e vice-versa. A segurança política abrange a estabilidade organizacional dos Estados, dos sistemas de governo e as ideologias que os legitimam. A segurança econômica trata do acesso a recursos, financiamento e mercados necessários à sustentação de níveis aceitáveis de bem-estar social e poder estatal. Esses são os temas de segurança abordados em Buzan (1991) que mais interessam neste estudo e que têm uma interconexão forte com o que podemos chamar de segurança em saúde como integrante da agenda de segurança nacional.

Em ampla literatura sobre segurança em saúde passou-se a defender uma visão coerente com a perspectiva liberal de um mundo economicamente globalizado e interdependente, pacífico e livre de disputas interestatais após o fim da Guerra Fria. Segundo essa visão, a agenda de segurança deveria ser tratada de forma coletiva, colaborativa e cooperativa, como um tema global e transfronteiriço, ou com foco na segurança humana de indivíduos, e não mais de nações, mas confiando-se em organizações internacionais, como a Organização das Nações Unidas (ONU) e a Organização do Tratado do Atlântico Norte (Otan), e na atuação benevolente dos Estados mais ricos e poderosos. A distinção tradicional entre atividades do setor Saúde doméstico e esforços internacionais na área seria desafiada pela globalização.

Segundo Colin McInnes (2008), a agenda de segurança em saúde trata de epidemias que, em um mundo globalizado com significativo fluxo de pessoas entre países, deveriam ser tratadas predominantemente de forma coletiva ou focada no indivíduo, o que não justificaria sua inclusão no campo da segurança nacional. Segundo Simon Dalby (2008), a segurança humana deve implicar um deslocamento do foco do Estado e território para as pessoas. A segurança humana significa a segurança relacionada a ameaças crônicas como fome, doença e repressão - que pode se relacionar com miséria

\footnotetext{
${ }^{6}$ Não concordamos com todas as especulações e visões de Buzan, especialmente sobre o cenário pós-Guerra Fria. No entanto, o autor tem contribuição fundamental para os estudos de segurança, por ter ampliado a agenda para outros temas, e para os fins deste estudo não é relevante discorrer sobre divergências em relação à visão e às especulações de Buzan sobre o futuro.
} 
e falta de acesso a condições mínimas de alimentação e salubridade em países subdesenvolvidos. ${ }^{7}$ Caroline Thomas (2008) reforça tal mudança ao afirmar que: 1) a questão da segurança se volta para seres humanos individuais e a proteção e cumprimento de seus direitos humanos; 2) a procura de outros níveis de seguridade - global, regional ou nacional - tem relevância e legitimidade na medida em que apoia a segurança humana; 3) a segurança humana não pode ser definida ou constrangida dentro de limites territoriais de uma unidade política exclusiva; 4) ao perseguir a segurança nacional, um Estado não deve comprometer a segurança humana de seus cidadãos ou ainda de pessoas que vivem além de seus limites territoriais.

Conforme McInnes (2008), na agenda de segurança sobre saúde têm sido tratados três temas principais: 1) a propagação de doenças infecciosas - tuberculose, gripe aviária, Aids, síndrome respiratória aguda severa (SARS, na sigla em inglês para severe acute respiratory syndrome), ebola para o "Ocidente" (como elemento exógeno); 2) pandemia de Aids/HIV (que pode ser inserido no anterior); 3) guerra biológica, em função da difusão e uso de armas biológicas por grupos radicais (bioterrorismo). Nesses temas, a saúde estaria diretamente ligada à questão da segurança, em função de potenciais efeitos desestabilizadores. Epidemias podem provocar, em curto período, um nível elevado de absenteísmo ou mesmo mortes, prejudicando o funcionamento do Estado e da economia, além de gerar um ônus significativo nos gastos públicos. Há também a possibilidade de revolta política, especialmente caso a população não acredite que está sendo atendida de forma adequada, ou que apenas segmentos mais privilegiados da população estão tendo acesso à assistência médica adequada. McInnes (2008) destaca o relatório da Central Intelligence Agency (CIA) de 1999 em que se argumenta que, com a globalização e os crescentes movimentos de pessoas e mercadorias, emerge o risco de que doenças infecciosas se espalhem globalmente e atinjam os cidadãos dos Estados Unidos da América (EUA), podendo afetar o crescimento econômico e a estabilidade internacional, e, consequentemente, tornar-se um problema de segurança nacional.

Em 2000, o Conselho de Segurança da ONU registra que a pandemia de Aids ameaça a segurança em razão de três efeitos: 1) o risco que representa para o funcionamento e a estabilidade do Estado nos campos econômico, social e político; 2) o fato de as forças de segurança (militares) e de paz serem potenciais difusores, pelo seu deslocamento; 3) a exacerbação de sua propagação em condições de violência. Levando em conta a hipótese de mobilidade de tropas em conflitos como vetor transmissor de doenças, McInnes (2008) argumenta que a relação entre epidemia de HIV e segurança não é muito conclusiva, visto que conflitos podem tanto impulsionar quanto restringir o deslocamento de tropas e civis, e, portanto, a disseminação do HIV. Além disso, programas de prevenção podem reduzir e efetivamente reduzem a propagação do HIV entre as tropas. Para o autor, as conexões alegadas - mecanismos de transmissão duvidosos - não garantem (não há evidências) que essas epidemias desestabilizem Estados.

\footnotetext{
7 Segundo Célia Almeida (2013: 239), "Na sequência do fim da Guerra Fria a principal mudança na nova agenda de segurança foi em relação ao próprio objeto da segurança - dos Estados para as pessoas - fragmentando a segurança nacional em várias subcategorias, procurando mudar o foco de análise do sistema interestadual para a sociedade e os indivíduos, seja dentro de determinado Estado ou entre Estados. Em 1994, o PNUD lançou a perspectiva da 'segurança humana', com o Relatório do Desenvolvimento Humano, acompanhada de várias recomendações para a institucionalização do conceito. O Fundo Monetário Internacional (FMI) e o Banco Mundial (BM) adotaram o conceito nas suas formulações, de forma bastante particular, assim como alguns países, sendo pioneiros a Noruega e o Canadá".
} 
Almeida (2013: 238-239) constata que

com o final da bipolaridade a "saúde global" deixou o espaço de low politic que ocupava desde a Segunda Grande Guerra e passou a integrar as agendas do Conselho de Segurança das Nações Unidas e do G-8, como tema importante do debate sobre a globalização e a segurança global. Na realidade é a "doença" e não "a saúde" que se transforma numa questão geopolítica. (...)

Entretanto, a partir dos meados dos 1990, com o fim da bipolaridade, as questões de segurança nacional começaram a ser revistas e as doenças infecciosas voltaram a ser consideradas nessa agenda. Pelo menos três desenvolvimentos chamam a atenção nessa nova articulação entre política externa e saúde: 1) o expressivo aumento no financiamento para a saúde; 2) o crescente número de atores e instituições que atuam nessa área; e 3) o impactante foco em apenas uma (HIV/Aids) ou poucas doenças (como tuberculose, malária).

Do nosso ponto de vista, atualmente, tratar o tema das guerras biológicas como tema de segurança em saúde não parece de interesse de países periféricos, especialmente de tradição pacífica, como o Brasil. No entanto, caso o país almeje obter uma projeção de ator global e influenciar o sistema internacional, deve estar preparado para possíveis ações hostis originadas de divergências de interesses com outros Estados militarmente fortes e/ou que dominam tecnologias de armas biológicas. McInnes (2008) sugere que não há evidências de que na mão de grupos radicais tais armas possam ser usadas como vetores eficazes na difusão de agentes biológicos ou químicos. Esses temas envolvem também o dilema entre cooperação coletiva e uma abordagem nacional para prevenção ou solução. Por outro lado, no discurso das grandes potências, os países periféricos podem ser identificados pelas potências como abrigos (voluntários ou não) de grupos radicais ou como focos de epidemias, o que justificaria práticas de "ajuda" e/ou intervenções.

A concepção aqui defendida, apoiada na perseguição a autonomia estratégica estatal em um sistema interestatal competitivo e anárquico, é de que a segurança em saúde deve ser tratada em perspectiva nacional, como tema de segurança e desenvolvimento nacional. A saúde deve ser encarada como um bem em si mesmo. A Organização Mundial da Saúde (OMS) define saúde como "um estado de completo bem-estar físico, mental e social, e não apenas a ausência de doenças". Seguindo a definição de Buzan (1991) para segurança econômica, poderíamos definir a segurança em saúde como o acesso a recursos, financiamento e mercados na área de saúde, necessários à sustentação de níveis aceitáveis de bem-estar social e poder estatal. Por seu caráter estratégico, o setor Saúde não pode ser tratado como parte da segurança econômica. E a segurança em saúde pode ser vista como a capacidade de um Estado (economia nacional) de produzir internamente os bens e serviços de saúde que atendam às necessidades de sua população, de forma a universalizar o acesso tanto em tempos de paz como diante de contenciosos e conflitos político-econômicos. Depende, assim, do domínio de tecnologias, da capacidade financeira e produtiva, e de mobilização de recursos em tempo hábil. Sobretudo, depende de um projeto nacional e de capacidade e coesão política interna para articular diferentes setores em prol desse objetivo superior, diante de possíveis constrangimentos e ações externas. É importante sublinhar que a segurança sanitária tem interconexões com outros temas de segurança, como a segurança econômica, a segurança política, a segurança militar e a segurança alimentar. 
Diante da necessidade ou da conveniência de importação, ou da inviabilidade da produção interna, seria fundamental para a segurança em saúde, nos termos definidos acima, que o país: em períodos de conflitos ou diante de contenciosos políticos, seja capaz (em tempo hábil) de mobilizar recursos para a produção de medicamentos antes importados; não dependa de fontes restritas de importação - seja(m) país(es) ou empresa(s); diversifique o máximo possível as fontes de importações (em termos de países e empresas, ou coalizões destes, consideranado a propriedade do capital das empresas); diversifique as rotas comerciais de abastecimento e fontes de financiamento. Sem embargo, a segurança sanitária e a segurança econômica têm relações estreitas, e vale aqui citar algumas delas.

Em relação à hierarquia monetário-financeira do sistema internacional, a proeminência do dólar como moeda internacional, assim como o papel desempenhado pelos serviços financeiros estadunidenses, dão maior liberdade e poder de arbítrio aos EUA. Assim, as relações comerciais e financeiras baseadas em dólar (como unidade de conta nos contratos ou meio de troca nas transações) podem ter seu valor alterado, e seu fluxo e acesso a crédito podem ser moldados (e dificultados ou mesmo interrompidos) a partir de decisões políticas nos EUA. É muito importante identificar origens e fluxos de financiamento e a denominação de contratos e de moedas em comércios bilaterais. Quando se trata de segurança em saúde, é necessário identificar a propriedade do capital das empresas que atuam no Brasil no âmbito do CEIS, especialmente as que participam de projetos produtivos (como as parcerias para o Desenvolvimento Produtivo, PDPs) com possibilidades de transferência tecnológica, assim como das empresas que fazem comércio com o Brasil (independentemente de sua localização territorial). Processos de concentração global da propriedade das empresas (por meio de fusões e aquisições) e da inovação tecnológica (patentes), com consequente processo de desnacionalização da indústria nacional, tendem a gerar vulnerabilidades econômicas e políticas, tornando vulneráveis a segurança em saúde e, de forma mais ampla, a segurança nacional.

A universalização do atendimento, com equidade e desconcentração geográfica pelo território nacional, tem papel fundamental na segurança política. A percepção de exclusão, por parte das classes menos favorecidas, de que somente a população mais rica (o Homo ricus de Diegues) tem acesso a bens e tecnologias de saúde de ponta, o que lhe provê uma qualidade e perspectiva de vida diferenciada, pode levar à fragmentação e a conturbações políticas internas e, consequentemente, a ameaçar a estabilidade organizacional do Estado, seu sistema de governo e a ideologia que o legitima. No tocante ao desenvolvimento e à ocupação do território nacional, além do caráter socioeconômico desenvolvimentista, a distribuição geográfica equitativa da oferta de saúde e (na medida do possível) da produção tem papel importante no domínio político do território e na sua segurança.

O economista norte-americano Thorstein Veblen (2001) afirma que capitalismo como um sistema social e econômico natural é um mito alimentado pela necessidade de justificar a forma como a produção e a riqueza são distribuídas entre os homens. Para Veblen, a produção só é possível em comunidade e, em uma perspectiva ontológica, depende da criatividade humana (instinct of workmanship). O estoque comum de conhecimentos, hábitos, costumes e meios de vida relativos à produção são, informalmente, mantidos pelo corpo social, constituindo-se em ativos intangíveis e equipamentos imateriais de toda a comunidade humana. 
Em uma perspectiva evolucionária da economia, torna-se cada vez mais difícil identificar a contribuição específica de um único indivíduo para o estado da arte da tecnologia ao longo da evolução histórica. Seguindo essa lógica poderíamos questionar, por exemplo, se Thomas Edison inventou a lâmpada (sozinho) fazendo uso exclusivo e estrito de sua capacidade individual ou se sua invenção foi o resultado final da aplicação de um estoque comum de conhecimentos da humanidade utilizados por ele para esse fim específico. Desse ponto de vista, relativiza-se a atribuição individual do monopólio sobre qualquer descoberta. A propriedade, para Veblen (2001), representa um confisco de uma parte, elemento ou fração determinada do equipamento imaterial da comunidade e tem um papel irrelevante na determinação da produtividade per se.

O sistema industrial, na lógica vebleniana, é identificado com a comunidade, e por sua interdependência fundamental (divisão do trabalho) corresponde à materialização ou à aplicação de uma herança de conhecimentos humanos (equipamentos imateriais e ativos intangíveis) cujo objetivo é servir à melhoria material e moral da comunidade. A tendência para a padronização dos produtos e processos industriais é consequência do fato de a indústria de massa requerer planejamento e coordenação, considerando-se que o modo de vida da comunidade seria mais bem atendido por um funcionamento ininterrupto e equilibrado do processo industrial. Além disso, para Veblen (2001), a ênfase nos processos de consolidação (fusões e aquisições, verticalização etc.) se dá mais por sua vantagem em relação ao controle do mercado e dos preços, e menos por sua maior eficiência e pela redução dos custos de transação.

O business é erigido sobre a indústria e a propriedade, e os lucros resultantes dessa atividade provêm da habilidade de excluir proporcionada pela propriedade. Negócios não são empreendidos por consideração à melhoria da vida da comunidade, mas, simplesmente, pelo objetivo de lucro. Sendo assim, os meios, métodos e objetivos do business são diferentes dos objetivos da indústria. Nesse sentido, o business é visto como uma atividade contraproducente no que diz respeito às atividades produtivas humanas, à sua criatividade e ao seu potencial econômico. A pergunta que deve ser feita, sob essa lógica, não é o que as empresas e corporações estão fazendo para o progresso da civilização em geral e da saúde, em particular, mas sim o que elas estão deixando de fazer.

A dicotomia entre indústria e business no campo da saúde é particularmente preocupante porque a saúde é um fator essencial ao bem-estar geral da humanidade. Se os objetivos do business farmacêutico divergirem dos objetivos da indústria farmacêutica, no sentido atribuído por Veblen (2001), um potencial avanço ou progresso para o bem-estar e a melhoria da saúde da população pode ser obstaculizado caso não atenda ao principal objetivo do business. Esse comportamento foi batizado por Veblen de sabotage. Um exemplo clássico de sabotage é o fenômeno da obsolescência planejada, em que o tempo de vida útil de um produto é restringido propositalmente pelos fabricantes, tornando o conserto e a reparação mais caros do que a compra de um produto novo.

Estendendo a visão de Veblen (2001) para a análise da indústria de saúde, uma questão a ser considerada em relação ao CEIS, e à indústria de saúde internacional de modo geral, é que as grandes empresas, em busca de lucros extraordinários a partir de posições privilegiadas, podem preferir não utilizar e não difundir, ou mesmo retardar a utilização, de avanços tecnológicos já alcançados - pro- 
movendo, assim, a sabotagem tecnológica ao invés do avanço tecnológico, o que seria contrário ao interesse público e à promoção da autonomia estratégica. Por outro lado, as empresas que concentram as inovações podem querer se aproveitar da sua posição privilegiada para impor altos custos à sua utilização, enquanto esta não for difundida, o que afeta o papel do Estado de universalizar o acesso de forma equânime atendendo a critérios de custo-efetividade. Esse debate sempre tem como pano de fundo a questão do Homo ricus (saúde para todos versus saúde para os ricos); no Brasil, a política do governo federal até 2014 deveria ter sido ampliada e intensificada, pois a doutrina básica que a orientava enfrentava tal questão na articulação entre poder de compra do Estado e desenvolvimento científico, tecnológico e industrial.

Defendemos, portanto, que o CEIS tem papel central tanto no âmbito socioeconômico quanto no político-estratégico. A construção do CEIS deve ter papel fundamental na autonomia estratégica e na segurança nacional, principalmente no que diz respeito à segurança econômica e à segurança política, além do potencial de conexão com a indústria de defesa (e consequentemente com a segurança militar). Por sua importância socioeconômica, sua participação no PIB e seu caráter tecnológico, e por reunir um conjunto de tecnologias portadoras de futuro e apresentar estreita interligação com a base industrial de defesa (que pode se tornar um complexo industrial de defesa), o desenvolvimento do CEIS é fundamental como vetor de crescimento, para a estabilidade interna, para a segurança interna e externa do país, para a redução de sua vulnerabilidade econômica e política, e para a ampliação do seu grau de independência nas suas relações exteriores. Além do caráter social, a universalização do acesso trabalha em favor da estabilidade política interna, ao eliminar diferenças internas em relação ao acesso da população a bens e serviços básicos. É importante para a segurança nacional do país também por torná-lo autossuficiente em períodos de conflitos ou interrupção de fluxos, e, assim, menos vulnerável a pressões internacionais e aos interesses (poder de barganha) de potências externas. Além disso, a distribuição das atividades do CEIS e a universalização do acesso aos bens e serviços de saúde por todo o território nacional (pelas suas diferentes regiões, inclusive fronteiriças) são importantes para o desenvolvimento socioeconômico do território nacional, para o seu aproveitamento em todas as suas potencialidades geográficas e da segurança do território nacional - ao promover o domínio político e a ocupação demográfica, econômica e militar adequada de todo o território e de seus recursos. Assim, considerando sua importância econômica, tecnológica, social, política e militar, o CEIS é uma indústria de caráter estratégico cujo destino não pode ser deixado ao mercado global, à vontade de potências externas e de organizações internacionais.

\section{Estados e tecnologias estratégicas: a área de saúde e o empreendimento militar}

Como fatores importantes na apropriação de poder e riqueza, a inovação tecnológica e, consequentemente, a capacidade de inovar são fundamentais na assimétrica e hierárquica distribuição de poder e riqueza no sistema interestatal, por sua relevância nos campos produtivo e militar, no aproveitamento e domínio de recursos, espaços e mercados.

Nas grandes potências, o papel do Estado e suas prioridades regulatórias refletem seus objetivos de manter a liderança nos campos produtivos de maior valor agregado e no campo científico e tecnológico de ponta, o que se reproduz no campo da indústria de saúde. Para as potências emergentes, os 
processos de catching up tecnológico se tornam a preocupação central no tocante à produção física e científico-tecnológica, para que o Estado alcance uma inserção ativa e favorável, e não subordinada, no sistema internacional (Chang, 2002; Medeiros, 2004; Chase-Dunn, Niemeyer \& Allison, 2005). Nesses processos, as ciências e as tecnologias ligadas à saúde são reconhecidas como ramos estratégicos, do ponto de vista social, econômico e de segurança nacional. As ligações entre a indústria militar e a indústria de saúde são aproveitadas e exploradas em suas potencialidades, ganhando centralidade tanto nos processos de manutenção de liderança quanto nos de emparelhamento tecnológico. E mesmo que os Estados usem estratégias para atrair para o seu território atividades produtivas e de pesquisa e desenvolvimento (P\&D) estrangeiras, trabalham para envolver atores nacionais, privados e até mesmo governamentais, para assegurar acesso e controle sobre o processo, tendo em vista a autonomia futura. Os setores que têm se destacado mais recentemente são ligados à biotecnologia e à nanotecnologia (Vargas, neste volume).

Uma questão fundamental a ser considerada é o tratamento especial dispensado à indústria de saúde e o papel determinante que esta desempenha na estratégia das grandes potências e tem exercido na estratégia de potências emergentes como a China e a Índia. No complexo industrial-militar dos EUA, as relações com o setor Saúde são intrínsecas, um modelo que tem sido copiado pelo complexo industrial-militar chinês (Medeiros, 2004; Medeiros \& Trebat, 2013). O setor Saúde sempre foi tido como estratégico pelas grandes potências, tanto em sua política interna quanto para sua projeção externa (o que transparece em sua postura de procurar acordos internacionais relativos a comércio, serviços, investimentos, propriedade e compras governamentais), e tem sido considerado dessa forma pelas potências emergentes. Por isso, o estudo de experiências comparadas, identificando benchmarks e ressaltando as particularidades brasileiras, pode ser um instrumento fundamental para recomendações políticas sobre como desenvolver a área de saúde e identificar os setores dentro do CEIS que podem ser priorizados, mas sempre levando em conta as particularidades do Brasil. Se observarmos as empresas líderes globais na produção e nas inovações, vamos encontrar predominantemente empresas estadunidenses, europeias e japonesas, e, em um processo de catching up, empresas chinesas, indianas e israelenses.

Ao longo de sua história e principalmente após a Segunda Guerra Mundial, no período da Guerra Fria, os EUA desenvolveram um arranjo institucional complexo e eficiente envolvendo empresas, universidades e agências governamentais, o chamado complexo industrial-acadêmico-militar, que teve nesse período e tem até hoje papel fundamental na sua liderança científica e tecnológica desde a ciência básica até tecnologias de ponta (cf. Smith, 1985). São inovações que transbordam do setor militar para o setor civil - caracterizando efeitos de spill over ou de spin off. Conforme destaca Medeiros (2004: 9),

O Advanced Research Projects Agency (Darpa), subordinado ao DOD [Departamento de Defesa], teve especial liderança na criação de novas tecnologias. Para este esforço, o fator limitante não era a disponibilidade de recursos financeiros. Depois da guerra, os militares obtiveram amplo apoio financeiro e as políticas de compra do DOD criaram uma vigorosa demanda protegida para as principais indústrias fornecedoras de armamentos. $\mathrm{O}$ fator limitante era o estoque de conhecimento e a estrutura operacional do sistema de inovações. Deste modo, a tarefa não se 
circunscrevia à provisão de incentivos para $P \& D$ nas indústrias ou nas universidades, mas na montagem de um extenso e dinâmico sistema de inovação. O desafio era reduzir o período de tempo entre as invenções e inovações acelerando o progresso técnico e dirigindo-o para a produção de "armamentos radicalmente novos". Este desafio foi assumido pelo DOD.

Diversos projetos e escritórios dentro do Darpa objetivam o desenvolvimento e a liderança científica e tecnológica, incluindo vários campos que exercem impacto sobre a indústria de saúde, como química, novos materiais, microeletrônica, ciência da computação, robótica, automação, biotecnologia, nanotecnologia, tecnologia nuclear, neurociências, entre outros. Entre eles destacamos o Defense Sciences Office (DSO), o Microsystems Technology Office (MTO) ${ }^{8}$ e o Biological Technologies Office (BTO), este último criado em abril de 2014.

Na página na internet do BTO, lançado em abril de 2014, o discurso do diretor do Darpa, Arati Prabhakar, salienta a relevância da biologia e define seu campo de inovação:

A biologia é o inovador final da natureza, e qualquer órgão focado na inovação seria insensato se não olhasse para esse mestre da complexidade em rede na busca de inspiração e soluções. (...)

[O BTO] irá fundir biologia, engenharia e ciência da computação para aproveitar o poder dos sistemas naturais para a segurança nacional.

Tecnologia, como a biologia, evolui constantemente. É missão do Darpa permanecer à frente da curva de mudança tecnológica, fazendo os investimentos fundamentais e iniciais em áreas que cubram os domínios da pesquisa e permitam novas capacidades revolucionárias para a segurança nacional dos EUA. Agora o Darpa está pronto para dar destaque sem precedentes para um campo de investigação que não pode mais ser considerado periférico à tecnologia envolvendo a natureza. A partir de hoje, a biologia toma o seu lugar no núcleo duro das ciências que representam o futuro da tecnologia de defesa. (Darpa, 2014, tradução nossa)

A liderança tecnológica em setores estratégicos é um dos elementos centrais para que um Estado consiga alcançar e manter uma posição hegemônica no sistema interestatal, tanto por seu impacto vantajoso na produção física quanto no poder militar, ou para que pelo menos figure no andar superior da hierarquia econômica e político-militar do sistema. Chase-Dunn, Niemeyer e Allison (2005:

4-5) argumentam que

Novas indústrias líderes têm sido elementos importantes no aumento e prolongamento das hegemonias econômicas no passado. Os poderes político e militar dos Estados são sustentados e facilitados por vantagens competitivas na produção de bens altamente rentáveis. Hegemonias crescentes (ou "líderes mundiais", na terminologia de Modelski e Thompson, 1996) conseguem

\footnotetext{
${ }^{8}$ Em sua página na internet, o BTO declara sua missão: "In recent years, the proliferation of commercial components and manufacturing processes has made advanced technologies accessible to all, leveling the playing field. In response, MTO is dedicated to leveraging, countering and transcending these commercial-off-the-shelf (COTS) approaches. MTO aims to multiply the power of COTS by aggregating, adapting and integrating components into networks and systems for the benefit of the warfighter. MTO seeks methods for countering threats (both incidental and intentional) that arise from sustained advancements in cheap and readily available technologies. Lastly, MTO develops high-risk, high-reward technologies outside and beyond the scope of the commercial industry to secure the DoD's technological superiority. By continuing to create revolutionary capabilities, MTO seeks to 'un-level' the playing field" (www.darpa.mil/Our_Work/MTO/).
} 
inovar novos modos rentáveis de comércio e produção que lhes permitam financiar vantagens políticas e militares em relação a outros Estados. Assim, a sequência de novas tecnologias líderes e sua distribuição pelo núcleo de Estados potencialmente concorrentes é um importante objeto de estudo para se compreender tanto o passado como o futuro da ascensão e queda de hegemonias. (tradução nossa)

Os autores chamam de "novas indústrias líderes" aquelas que transbordam tecnologias para outros setores, têm capacidade de gerar "rendas tecnológicas" (monopolísticas) por determinado período, influenciando inclusive a indústria militar. Assim, o domínio de tecnologias líderes ou estratégicas tem implicações geopolíticas sobre a distribuição de poder econômico e militar, e suas rivalidades. Olhando especificamente para a hipótese de declínio da hegemonia dos EUA, os autores afirmam:

Depois que surgiu maior competição internacional, os EUA continuaram a angariar rendas tecnológicas por inventar, produzir e exportar novos produtos, incluindo equipamentos de energia nuclear, tecnologia militar e tecnologia da informação. Agora, muitos acreditam que as vantagens dos EUA no campo da biotecnologia poderão contribuir substancialmente para uma nova rodada de hegemonia econômica dos EUA nas próximas duas décadas. (Chase-Dunn, Niemeyer \& Allison, 2005: 5, tradução nossa)

Assim, apostam as indústrias de biotecnologia, de alimentos e medicina na posição futura dos EUA nos próximos dois séculos, fazendo uma associação entre ciclos de liderança tecnológica e ciclos hegemônicos. ${ }^{9}$

Chase-Dunn, Niemeyer e Allison (2005) registram que, em 1984, o Office of Technology Assessment (OTA) do Congresso dos EUA realizou um influente estudo comparativo sobre as vantagens do país na área biotecnológica e concluiu que esta deveria ser impulsionada com significativos investimentos privados e públicos. No mesmo estudo, o OTA indica os dez fatores-chave para a competitividade internacional na biotecnologia (em ordem decrescente de importância):

1) financiamento e incentivos fiscais para empresas;

2) fundos governamentais para pesquisa básica e aplicada;

3) treinamento e disponibilidade de pessoal;

4) regulação de saúde, seguridade e ambiental;

5) lei de propriedade intelectual (no caso dos EUA, importante para proteger suas firmas em seu processo de expansão global);

6) relações indústria-universidade;

7) lei antitruste;

8) transferência de tecnologia, investimentos e comércio internacionais;

9) metas de políticas públicas em biotecnologia; e

10) percepções públicas (mais importante no caso dos alimentos).

\footnotetext{
${ }^{9}$ Esse argumento foi utilizado anteriormente por Joachim K. Rennstich (2001, 2004).
} 
Para Chase-Dunn, Niemeyer e Allison (2005), alguns importantes fatores foram esquecidos nessa lista. Os acordos e instituições internacionais, as trajetórias de competição econômica, política e militar, e possibilidades de conflitos, assim como as condições da economia política global como um todo devem ser levadas em conta, porque influem nas regras do jogo e nas possibilidades e formas de acesso a financiamento, comércio, investimentos e transferências tecnológicas. Essa abordagem indica que, além da importância do comportamento dos agentes (Estados), é preciso olhar para o comportamento da estrutura, que pode gerar constrangimentos e fatores balizadores. Do nosso ponto de vista, além de um projeto nacional liderado pelo Estado, coeso internamente e em sua projeção externa, a distribuição de poder e as possibilidades de cooperação e conflito no sistema internacional são fatores importantes para quem larga atrás na busca por novas tecnologias e posições políticas e econômicas no sistema internacional.

Olhando para as barreiras à entrada na indústria biotecnológica, um consenso na literatura, Chase-Dunn, Niemeyer e Allison (2005) aceitam que existem altos custos de entrada em P\&D para nações e firmas retardatários. No entanto, argumentam que esses custos não são tão altos, visto que há exemplos de países que superaram essas barreiras, como a China e Cingapura - o primeiro deles contando com um amplo mercado e mobilização de recursos. Isso revela que a competição pela liderança tecnológica (e seus benefícios) tende a se acelerar nos próximos anos:

Supostamente, os altos custos iniciais de pesquisa e desenvolvimento de biotecnologia deveriam retardar o surgimento de concorrentes. Isso tem sido visto como parte da explicação para o fato de a pesquisa em biotecnologia, desenvolvimento e comercialização na Europa e no Japão ter ficado para trás em relação aos EUA. Entretanto, tem havido alguns desenvolvimentos que lançam dúvidas sobre essas caracterizações. A República Popular da China começou uma iniciativa em biotecnologia substancial patrocinada pelo Estado nos anos 1980, e muitas inovações importantes desse programa foram implementadas em larga escala na agricultura chinesa, com, em tese, grandes efeitos benéficos. Talvez o grande tamanho da China semiperiférica tenha permitido que os recursos maciços fossem concentrados em esforços de pesquisa e desenvolvimento direcionados, de forma que esse desenvolvimento não se mostra tão surpreendente. Mas Cingapura, uma cidade-estado no sudeste da Ásia, também conseguiu estabelecer uma indústria de biotecnologia com sucesso, importando talento científico do exterior. Esses iniciantes demonstram que a entrada no setor de biotecnologia não é tão restrita como se supunha, e que a concorrência por fatias da demanda mundial dos produtos biotecnológicos acelerará o ciclo do produto, tornando mais difícil para determinados países, incluindo os EUA, angariar rendas tecnológicas por muito tempo. (Chase-Dunn, Niemeyer \& Allison, 2005: 11, tradução nossa)

Em interessante artigo sobre o complexo industrial da saúde e a rota biotecnológica, Reis, Landim e Pieroni (2011) tratam de lições da experiência internacional examinando o processo de catching up de China, Índia e Israel. Os autores enfatizam a importância do papel do Estado na contrução de um arcabouço regulatório e institucional favorável ao desenvolvimento produtivo e científico-tecnológico da rota biotecnológica. No entanto, por questões de escopo, no artigo não salientam que esses três países contam com uma vigorosa indústria militar e lidam com questões geoestratégicas (principalmente, vizinhanças conturbadas) que criam pressões por avanços em áreas-chave e, ao menos no caso de China e Israel, uma intensa ligação entre indústria de saúde e complexo industrial-militar. 
A Índia, embora não tenha um complexo industrial-militar bem formado, constituiu uma estratégia estatal e regulatória com o objetivo de avançar na biotecnologia e conta com uma base de cientistas habilidosos e um aparato regulatório que facilitam as transferências e a apropriação de tecnologias de empresas estrangeiras. No caso de Israel, conta seu papel como aliado estratégico e receptor de amplo apoio dos EUA nos campos militar, econômico e tecnológico.

Medeiros e Trebat (2013) mostram que a China tem se inspirado no complexo militar-acadêmicoindustrial estadunidense para constituir seu poder militar-tecnológico, envolvendo setores ligados à indústria de saúde:

O pensamento de elite na China no que diz respeito à integração civil-militar sofreu uma mudança significativa na segunda metade da década de 1980. O foco intenso na conversão de defesa, acompanhado da Iniciativa de Defesa Estratégica da administração Reagan, convenceu oficiais e cientistas proeminentes de que não estava sendo feito o suficiente para promover investimentos em áreas de alta tecnologia fundamentais para a segurança e a competitividade econômica da China. Para resolver esse problema, a China criou o "Programa 863 de pesquisa em alta tecnologia" em 1986, com foco em automação, biotecnologia, energia, tecnologia da informação (TI), laser, novos materiais e espaço. Como o Darpa, porém com um foco maior na pesquisa aplicada, o Programa 863 oferece financiamento numa base competitiva para as universidades, institutos de pesquisa do governo e laboratórios industriais envolvidos em pesquisa de alta tecnologia com potenciais aplicações militares.

Embora os níveis de financiamento fossem bastante baixos até o início da década de 1990, o 863 evoluiu para o "principal instrumento de política para a indústria de alta tecnologia" e "o maior programa nacional da China" para a pesquisa e desenvolvimento. O financiamento aumentou no fim dos anos 1980 e 1990 com o aumento da importância de programas científicos de base militar no processo de modernização da China. (Medeiros \& Trebat, 2013: 7-8, tradução nossa)

Os autores destacam oito indústrias civis que apresentam maior potencial para a tecnologia militar. Muitas delas exercem impacto sobre a indústria de saúde:

microeletrônica, computadores, equipamentos de telecomunicações, energia nuclear, biotecnologia, química, aviação e espaço. Embora a China fique atrás dos EUA e de outros países industrializados em todas essas áreas, a distância está encurtando em relação à maioria deles e o complexo militar-industrial-científico chinês está rapidamente se tornando mais sofisticado. (Medeiros \& Trebat, 2013: 14, tradução nossa)

As experiências históricas de grandes potências e das potências emergentes apontam para o desenvolvimento prioritário da indústria de saúde em suas estratégias nacionais de segurança e desenvolvimento. O Estado tem o papel de liderar o processo de construção da indústria de saúde. Estratégias lideradas pelo Estado, bem planejadas, com adequadas regulações, mobilização de recursos e arranjos institucionais envolvendo setores estatais, acadêmicos e empresariais são condições necessárias para um processo bem-sucedido de catching up nas indústrias estratégicas. É importante notar o potencial de conexão entre o desenvolvimento tecnológico no setor militar e no CEIS, no campo nuclear, da biotecnologia, da nanotecnologia, das ciências de materiais e nos equipamentos. 
Em geral, essa percepção costuma vir das estratégias de formação da indústria de defesa, ao envolver a área da saúde. Os segmentos que formam o CEIS são constituídos por indústrias portadoras de tecnologias de futuro, com caráter estratégico, que se espalham por outros setores da economia e são fundamentais para o desenvolvimento e a segurança nacional.

Se o Brasil quiser trilhar um caminho bem-sucedido na consolidação do CEIS, é preciso que este seja considerado como um setor estratégico para o desenvolvimento e a segurança nacional, e que se explorem as articulações entre o CEIS e a base industrial de defesa em todas as suas potencialidades, com intensa participação do Estado. A articulação entre a estratégia nacional de defesa e a política nacional de defesa com as políticas do Ministério da Saúde e do Ministério de Ciência e Tecnologia para a área da saúde seria imprescindível para a formação de clusters ou arranjos produtivos envolvendo empresas privadas nacionais e estrangeiras, universidades e o Estado, especialmente na questão do financiamento, na qual o Banco Nacional de Desenvolvimento Econômico e Social (BNDES) pode ter papel fundamental. Tais arranjos deveriam se direcionar para uma pujante dinâmica produtiva física e científico-tecnológica, garantindo transferências e autonomia tecnológica a longo prazo.

\section{O Brasil e as Macrotendências Globais}

A partir dos anos 1970, o sistema interestatal presenciou um ciclo geopolítico e geoeconômico de aceleração de sua permanente competição entre Estados pelo controle e acesso privilegiado a mercados e territórios que contenham recursos estratégicos ou sejam importantes rotas para comercialização eficiente e segura (Klare, 2008; Fiori, Padula \& Vater, 2013). Trata-se de recursos que, em termos globais, são relativamente escassos e/ou estão concentrados em alguns territórios, predominantemente nos países de menor grau de desenvolvimento socioeconômico e poder político-militar, e que ao mesmo tempo são cruciais para a expansão industrial e do poder militar de países ricos e militarmente fortes, com maior influência no sistema internacional.

A recente aceleração competitiva se deve a diversos fatores. A perda relativa de poder ou "crise de hegemonia" - impulsionada, desde a crise do padrão dólar-ouro, pelo fracasso no Vietnã e pela perda de influência em posições importantes no Oriente Médio nos anos 1970 - levou os EUA a retraçarem sua estratégia de expansão para enquadrar possíveis rivais e vencer a Guerra Fria, abandonando sua "hegemonia benevolente" - que inclusive apoiava ou tolerava políticas desenvolvimentistas e de welfare state em Estados da periferia capitalista. Além disso, no pós-Guerra Fria, o surgimento das chamadas potências emergentes da Ásia (com grandes populações e crescentemente demandantes de recursos), principalmente China e Índia, e a retomada de uma política nacionalista da Rússia, nos anos 2000, fazendo frente ao desejo de potências tradicionais de manterem suas posições, pressionam ainda mais essa corrida dentro da dinâmica do sistema estatal (Fiori, Padula \& Vater, 2013).

A prevalência da potência capitalista na confrontação bipolar e o discurso da globalização trouxeram a promessa de um mundo mais pacífico (o fim da história de Fukuyama, 1992) e convergente em termos de renda, riqueza e tecnologia, entre os países subdesenvolvidos e os desenvolvidos, promovido por meio das livres forças de mercado e da interdependência econômica global (comercial, financeira e tecnológica). Com base nessa ideologia ou por meio de pressões políticas - lideradas pelos Estados 
centrais e organizações internacionais sob sua influência (como o Fundo Monetário Internacional e o Banco Mundial) -, foi promovido um amplo processo de liberalização econômica global no setor industrial, mediante iniciativas unilaterais ou acordos bilaterais entre Estados, e ainda no âmbito multilateral por intermédio da Rodada Uruguai do Acordo Geral sobre Tarifas e Comércio (Gatt) e da Organização Mundial do Comércio (OMC). Dessa agenda de acordos liberalizantes baseados na ideologia da globalização resultaram o Gatt e o Gats, sobre liberalização e transparência no comércio, respectivamente, de bens e de serviços; o Trade-Related Aspects of Intellectual Property (Trips), relativo à propriedade intelectual; o Agreement on Trade-Related Investment Measures (Trims), relativo a investimentos, e mesmo o Tratado de Não Proliferação Nuclear (TNPN). Nessa perspectiva de mundo pacífico e livre de disputas interestatais, a segurança deveria ser tratada de forma cooperativa, como um tema global e transfronteiriço, confiando-se em organizações internacionais (como a ONU e a Otan) e na atuação benevolente dos Estados mais ricos e poderosos, tirando a nação do centro do debate. Daí surge a ideia de que epidemias, em um mundo globalizado e com significativo fluxo de pessoas entre países, deveriam ser tratadas predominantemente de forma coletiva. Ou de que o tema da segurança humana em países subdesenvolvidos deveria ser tratado em uma perspectiva focada no indivíduo ou cosmopolita (McInnes, 2008).

No entanto, o sistema internacional pós-Guerra Fria continuou sendo caracterizado por sua estrutura assimétrica de distribuição de poder e riqueza e por sua natureza anárquica e competitiva interestatal. Ampliaram-se as divergências de renda, riqueza e tecnologia (revelada no registro de patentes de tecnologias de ponta), ao mesmo tempo que a atividade industrial se concentrou cada vez mais nos países desenvolvidos e militarmente poderosos (com exceção dos países do sudeste asiático) ${ }^{10}$ e os conflitos militares não foram eliminados, só se aceleraram (Fiori, Padula \& Vater, 2013). No mesmo sentido, aumentou a dependência econômica e tecnológica dos países subdesenvolvidos, inclusive na área da saúde, ${ }^{11}$ e a diferença entre seu poder militar e político e aquele dos países desenvolvidos foi se acentuando.

Por suas dimensões, seus mercados e recursos estratégicos, o Brasil, a América do Sul e a África estão inevitavelmente inseridos na crescente competição das grandes potências. O Brasil é um país continental. Se fizermos listas de países segundo tamanho do território, população e PIB, apenas cinco países estarão entre os dez primeiros de cada uma delas: os Estados Unidos, a China, Índia, Rússia e Brasil. O Brasil é o quinto país do mundo em território e população, e oscila entre a sexta e sétima posição em termos de PIB nominal. Assim, é um país grande, com dimensões que trazem grandes oportunidades, desafios e responsabilidades, e não pode sofrer com o que Reis (2011: 63, 64) chama de "síndrome de Costa Rica". É um país que tem que trilhar um caminho próprio e buscar o lugar que lhe cabe no mundo, e cujo crescimento e projeção externa impactam na expectativa de outros atores e desperta rivalidades com outros Estados.

\footnotetext{
${ }^{10}$ Ao longo dos anos 2000, os relatórios da UNCTAD (Trade and Development Report) abordam esse processo impulsionado pela liberalização dos anos 1980 e 1990.

${ }^{11}$ Ver volumes 1 e 5 da série A Saúde no Brasil em 2030: prospecção estratégica do sistema de saúde brasileiro: desenvolvimento, Estado e políticas de saúde. Rio de Janeiro: Fiocruz, Ipea, Ministério da Saúde, Secretaria de Assuntos Estratégicos da Presidência da República, 2013.
} 
Especificamente no concernente à América do Sul e seu lugar na política de segurança dos EUA, é importante considerar sua posição geográfica relativa em área geoestratégica, de interesse e ação permanente por parte dos EUA. A postura intervencionista e imperialista estadunidense na região se respalda na sua geoestratégia de se tornar árbitro político e exercer controle sobre a massa de recursos do hemisfério ocidental, não deixando que surja nenhuma potência ou coligação de países no continente americano, ou mesmo aliada a uma potência do hemisfério oriental, que possa vir a contestar ou a ameaçar seu predomínio hemisférico, por razões de segurança territorial. Essa concepção geopolítica foi formulada por Nicholas Spykman (1942), para quem a supremacia estadunidense no continente deve ser incontestável e irrevogável para a sua segurança territorial. ${ }^{12}$ Em resumo, a atuação intervencionista e a manutenção da hegemonia dos EUA no hemisfério teriam basicamente duas razões entrelaçadas: a construção de um possível sistema econômico e político autárquico sob a hegemonia de Washington e sua segurança territorial, que quando ameaçados poderiam provocar respostas, em última instância, baseadas no uso da força (Padula, 2013).

Durante o segundo governo Lula, o Estado brasileiro definiu uma nova política de desenvolvimento e de defesa, a partir da formulação do seu Plano Nacional de Defesa (PND) e da sua Estratégia Nacional de Defesa (END), aprovados pelo Congresso Nacional, respectivamente, em 2005 e 2008, e de suas reformulações em 2012. Na END, declara-se:

O Brasil é pacífico por tradição e por convicção. Vive em paz com seus vizinhos. Rege suas relações internacionais, dentre outros, pelos princípios constitucionais da não intervenção, defesa da paz e solução pacífica dos conflitos (...).

Porém, se o Brasil quiser ocupar o lugar que lhe cabe no mundo, precisará estar preparado para defender-se não somente das agressões, mas também das ameaças. Vive-se em um mundo em que a intimidação tripudia sobre a boa-fé (...).

Estratégia nacional de defesa é inseparável de estratégia nacional de desenvolvimento. Esta motiva aquela. Aquela fornece escudo para esta. Cada uma reforça as razões da outra. Em ambas, se desperta para a nacionalidade e constrói-se a Nação. Defendido, o Brasil terá como dizer não, quando tiver que dizer não. Terá capacidade para construir seu próprio modelo de desenvolvimento (...).

Difícil - e necessário - é para um país que pouco trato teve com guerras convencer-se da necessidade de defender-se para poder construir-se. (Brasil, 2008: 8)

A END baseia-se na noção de que para a independência nacional é essencial a autonomia tecnológica e produtiva na área de defesa, formando a base industrial de defesa nacional.

Esses documentos delimitam o "entorno estratégico" do Brasil como espaço de atuação prioritário de sua política externa e de defesa, definindo a região sobre a qual o Brasil se propõe irradiar a sua influência e projetar sua liderança diplomática, econômica e militar, que engloba a América do Sul, a costa ocidental da África, a Antártida e o Atlântico Sul. Dentro do seu próprio território, o Brasil

${ }^{12}$ No entanto, suas raízes podem ser encontradas nos founding fathers, na Doutrina Monroe (1823) e seu Corolário Roosevelt (início do século XX), que pretendiam, em uma perspectiva estadunidense, afastar as potências europeias do continente de modo a preservá-lo para a hegemonia e controle dos EUA. 
definiu como regiões prioritárias para ocupação econômica e defesa de suas áreas a bacia Amazônica e a bacia do Prata, além da conquista de um acesso múltiplo e contínuo à bacia do Pacífico, por meio da construção de um sistema integrado de transporte, comunicação e defesa do território sul-americano (Fiori, Padula \& Vater, 2013).

As potências tradicionais e emergentes têm promovido uma série de acordos bilaterais e regionais, principalmente diante das complicações persistentes na conclusão da Rodada de Doha da OMC. Com os acordos regionais recém-firmados, EUA e União Europeia procuram aprofundar a regulação em temas já presentes na agenda da OMC, os chamados OMC-plus - regras de origem, salvaguardas, serviços e propriedade intelectual - e em novos temas, os OMC-extra - concorrência, compras governamentais, meio ambiente e legislação trabalhista. Uma diferença relevante é que os EUA e a União Europeia têm procurado firmar acordos focados no aprofundamento de compromissos relativos à propriedade intelectual e nos novos temas, sem discutir subsídios agrícolas. China e Índia têm promovido uma série de acordos, no entanto mais focados na liberalização de mercados, no acesso a investimentos e na regulação de subsídios.

Esses acordos chegam com força à América Latina, e mais especificamente à América do Sul, no entorno estratégico brasileiro. Os acordos bilaterais de livre-comércio realizados entre EUA e Chile, Colômbia e Peru apresentam como característica comum a ampla abrangência de temas. Indo além da redução de tarifas, envolvem questões negociadas na OMC (OMC-plus) e não tratadas no âmbito da organização (OMC-extra), como: regras de origem, salvaguardas, serviços, proteção à propriedade intelectual, transparência regulatória, controle de pirataria, falsificação e invasão virtual, proteção de copyright, patentes e marcas registradas, acesso a compras governamentais, leis de concorrência (e livre acesso a mercados), leis trabalhistas - com incentivo à fiscalização e ao cumprimento das leis contidas na Declaração da Organização Internacional do Trabalho (OIT) de 1998 -, regulação ambiental, comércio eletrônico e melhoria no setor de telecomunicações. Os tratados bilaterais apresentam resoluções que conferem a empresas estadunidenses a ampliação de sua atuação no outro país sem discriminação e a proteção a esses investidores, sem discriminação em relação às empresas nacionais, para estabelecer a livre concorrência (Padula, 2013).

Embora os países subdesenvolvidos tenham se articulado e alcançado a Declaração de Doha para flexibilizar o Trips em favor da área da saúde (Almeida, 2013: 276), ${ }^{13}$ atualmente as grandes

\footnotetext{
${ }^{13}$ Para Almeida (2013: 276): "As implicações do Acordo TRIPS para a saúde pública levaram os países em desenvolvimento a proporem, e obterem, a adoção da Declaração de Doha, cujas flexibilidades seriam 'necessárias à proteção da saúde pública e nutrição'. Isso ocorreu em abril de 2001, quando o governo norueguês sediou uma reunião que incluiu OMS, UNICEF, Banco Mundial, as grandes indústrias farmacêuticas transnacionais e poucas ONGs, para discutir estratégias que possibilitassem melhoria de acesso dos países pobres a drogas e medicamentos de alto custo. Embora a questão de licença compulsória tenha sido considerada, a reunião terminou por aprovar a proposta de 'preços diferenciais' para países de baixa renda, que continuou a favorecer a indústria farmacêutica. Essa proposta foi endossada sete meses depois, na reunião do Conselho de Ministros da OMC, em Doha em 2001, que adotou a Declaração de Doha (o Doha Statement on TRIPS and Public Health), que reafirmou as flexibilidades previstas no Trips para apoiar problemas relacionados à saúde e reiterou os direitos dos países de usarem a licença compulsória para a produção e melhoria do acesso aos medicamentos genéricos. O princípio subjacente a essa Declaração é que a saúde pública teria prioridade sobre as regras do comércio internacional e, para tal, afirma a legitimidade da licença compulsória assim como certas flexibilidades no Acordo TRIPS para países que não dispõem de desenvolvimento industrial. A reunião de Doha comissionou um processo de elaboração de regulamentos para essas situações".
} 
potências, e especialmente os EUA, têm firmado acordos bilaterais e regionais que estabelecem regras e direitos de propriedade intelectual que vão além do Trips (conhecidos como Trips Plus). ${ }^{14}$

Os Estados Unidos têm promovido acordos de livre-comércio e arranjos de integração aberta no hemisfério ocidental, na Ásia-Pacífico e no Atlântico Norte. Assim, tais acordos alcançam cada vez mais o entorno estratégico brasileiro. Na América Latina, os EUA lideraram a criação do Nafta (Área de Livre Comércio da América do Norte) em 1994. Em relação aos países da América do Sul, após o fracasso do seu projeto da Área de Livre Comércio das Américas (Alca) - entravado sob a liderança de Argentina, Brasil e Venezuela na Cúpula de Mar del Plata de 2005 -, têm estabelecido tratados de livre-comércio (TLCs) bilaterais, especialmente com as pequenas economias exportadoras de commodities da costa do Pacífico - Chile e Peru - e com seu aliado estratégico na região - Colômbia. Nas negociações bilaterais, os EUA exercem um poder de barganha mais direto e assimétrico, alcançando maiores vantagens que em negociações multilaterais - como acesso a compras governamentais, investimentos e serviços financeiros, direitos de propriedade intelectual, e mesmo acordos militares. A partir de uma teia de acordos bilaterais, os EUA tentam liderar um bloco econômico liberal na América do Sul, contraposto ao Mercado Comum do Sul (Mercosul) e minando a União de Nações Sul-Americanas (Unasul) - projetos liderados pelo Brasil -, para conter a influência do Brasil e o avanço da China (Fiori, Padula \& Vater, 2013; UNCTAD, 2007).

Com abrangência geográfica mais ampla, os EUA assinaram em 4 de fevereiro de 2016 o acordo da Trans-Pacific Partnership (TPP), ainda a ser aprovado no seu Congresso, e têm liderado as negociações da Transatlantic Trade and Investiment Partnership (TTIP), ${ }^{15}$ que somadas atuam para isolar os Brics - Brasil, Rússia, Índia, China e África do Sul (Padula, 2013; Fiori, Padula \& Vater,

\footnotetext{
14 “A resposta dos EUA e da Europa foi desconsiderar esse acordo negociado na OMC e começar a negociar acordos livres bilaterais e regionais, o que envolve a aceitação de concessões dos países em desenvolvimento, parceiros desses acordos (...). A questão da propriedade intelectual nesses acordos bilaterais e regionais (chamados 'TRIPS plus') proporciona muito mais proteção para as grandes indústrias farmacêuticas do que os TRIPS originais da OMC. (...) Desde 2001 qualquer acordo comercial norte-americano inclui aspectos relativos à proteção do direito de propriedade intelectual dos fármacos por período mais longo que os 20 anos previstos no TRIPS. Esse padrão 'TRIP-plus' erodiu de forma importante as flexibilidades previstas na Declaração de Doha" (Almeida, 2013: 278).

${ }^{15}$ De 11 a 14 de março foi realizada em Bruxelas, Bélgica, a quarta rodada de negociações do Acordo de Parceria Transatlântica de Comércio e Investimento (TTIP, sigla em inglês) entre os Estados Unidos e a União Europeia (UE). Foram registrados progressos nas três áreas principais de negociação. Primeiro, com relação a acesso a mercados, examinaram-se maneiras de avançar para o intercâmbio de ofertas sobre contratação pública e comércio de serviços (tal intercâmbio já havia sido realizado para as mercadorias). Segundo, foram discutidos assuntos relacionados com regulamentação: coerência e compatibilidade regulatória, barreiras técnicas ao comércio e medidas sanitárias e fitossanitárias. Terceiro, deu-se continuidade ao desenvolvimento de enfoques inovadores relacionados com regras sobre desenvolvimento sustentável, padrões trabalhistas e ambientais, comércio de energia e matérias-primas, e facilitação do comércio e procedimentos alfandegários. Deve-se mencionar também que os Estados Unidos e a UE publicaram em conjunto um documento sobre as oportunidades que o TTIP dispõe para as pequenas e médias empresas e como se planeja ajudar essas empresas a aproveitar o acordo. A 15 a rodada ocorreu em outubro de 2016 em Nova York, ainda sem conclusão das negociações.
} 
2013). ${ }^{16}$ O TPP foi a pedra angular da política econômica do governo Obama na Ásia-Pacífico. O acordo inclui Chile, México e Peru, e exclui a China. No âmbito do TPP foi negociado um amplo e ambicioso acordo de liberalização, que envolve amplos pacotes, abrangendo: livre circulação de bens (com eliminação de tarifas em cerca de 11 mil linhas tarifárias), serviços (especialmente financeiros) e investimentos; asseguração do máximo acesso recíproco a compras governamentais; estabelecimento de regras comuns de origem; eliminação de obstáculos ao comércio e ao investimento dentro das fronteiras dos países (com apoio técnico e financeiro dos países do TPP); respeito aos direitos de propriedade; acordos relativos a propriedade intelectual (inclusive em farmacêuticos), visando a reforçar e desenvolver o acordo da OMC sobre os Trips, mas supostamente comprometidos com a Declaração de Doha. O texto negociado garante a um investidor privado o direito de iniciar o processo de resolução de litígios contra um governo estrangeiro em seu próprio direito sob a lei internacional, caso o governo viole tratados ou mude regras de forma a prejudicar o investidor e suas possibilidades de lucro. Sem dúvida, tal texto implica uma violação do princípio da soberania nacional.

Os congressistas estadunidenses ${ }^{17}$ têm mostrado preocupação com a possibilidade de que o TPP se concentre em proteger a propriedade intelectual em detrimento dos esforços para proporcionar o acesso a medicamentos a preços acessíveis nos países em desenvolvimento. Há também um temor de que o TPP não seja suficientemente flexível para acomodar os programas de reembolso de medicamentos não discriminatório e os diversos sistemas de saúde dos países-membros já existentes. Entre diversos exemplos, os opositores do TPP argumentam que as corporações estadunidenses teriam acesso a mercados e minariam esforços para proporcionar o acesso a medicamentos a preços acessíveis no Vietnã, e estariam esperando para enfraquecer a capacidade da Pharmac de obter medicamentos genéricos de baixo custo, forçando a Nova Zelândia a pagar por medicamentos de marca. Médicos e organizações como Médicos Sem Fronteiras também manifestaram preocupação.

As negociações ocorreram em ritmo acelerado, e o presidente Barack Obama assinou o acordo em fevereiro de 2016, dependendo apenas da aprovação do Congresso dos EUA. ${ }^{18}$ As empresas estadunidenses, principalmente a indústria farmacêutica, que tem lobby fortíssimo, mostraram enorme interesse em resguardar seus direitos de propriedade intelectual nos moldes do Trips e ter acesso às

${ }^{16}$ Originado em 2005 como um acordo limitado entre quatro países do Pacífico - Brunei, Chile, Nova Zelândia e Cingapura -, contou com a adesão às negociações de Austrália (2008), Canadá (2012), EUA (2008), Japão (2013), Malásia (2010), México (2012), Peru (2010) e Vietnã (2008). O TPP ganhou relevância na Ásia-Pacífico em novembro de 2009, quando o presidente Obama anunciou a intenção dos EUA de participar de suas negociações para concluir um ambicioso acordo na Ásia-Pacífico (um "novo acordo do século XXI", de "nova geração") e de reforçar a sua participação nas economias dinâmicas da Ásia. Desde então, Washington ditou o ritmo das negociações até sua assinatura em fevereiro de 2016 para o acordo que refletir as suas prioridades econômicas e a ampliação da participação de países da região - como anunciado por Obama.

${ }^{17}$ As informações constantes neste parágrafo estão disponíveis nos seguintes documentos: Letter from 10 Representatives asking for a meeting to discuss IP policies that could undermine public health and access to medicines, 3 August 2011; Letter from Senator Sanders to US Trade Representative Ron Kirk, 1 December 2011; Letter from Representatives Levin, Waxman, McDermott, and Conyers to US Trade Representative Ron Kirk.19 October 2011; Letter from Reps. Lewis, Stark, Rangel, Blumenauer, and Doggett asking that the May $10^{\text {th }}$ agreement serve as a "non-negotiable starting point" for access to medicines, 8 September 2011.

${ }^{18}$ Em 12 de novembro de 2011, os líderes de nove países do TPP - Austrália, Brunei, Chile, Malásia, Nova Zelândia, Peru, Cingapura, Vietnã e EUA - anunciaram a concretização do esboço de um acordo e, após 16 rodadas de negociações e progressos significativos, as negociações estão em ritmo acelerado (cf. USTR, 2011). 
compras governamentais e mercados dos demais países do TPP. É exatamente por isso que reafirmamos que a pedra angular da política econômica da administração Obama na Ásia Pacífico manifesta-se no TPP, para impulsionar

o crescimento econômico dos EUA e apoiar a criação e manutenção de empregos americanos de alta qualidade por meio do aumento das exportações em uma região que inclui algumas das economias mais robustas do mundo e representa mais de $40 \%$ do comércio mundial. (...) [o governo dos EUA] está tentando concluir um acordo forte, que aborda as questões que as empresas norte-americanas e os trabalhadores estão enfrentando no século 21. (USTR, 2011, tradução nossa)

Assim como nas negociações bilaterais, no âmbito do TPP, países com enormes assimetrias se envolvem na negociação de amplos acordos de liberalização, muito além do campo comercial, que almejam assegurar um amplo mercado e posições privilegiadas com ganhos extraordinários para as grandes empresas transnacionais estadunidenses, especialmente as relacionadas à área da saúde. Ao mesmo tempo, minam a possibilidade de florescimento de indústrias nesses países e dificultam a competitividade de empresas de países que não tenham os mesmos acordos, ou deles façam parte, e que poderiam promover suas indústrias ou arranjos cooperativos. Por isso, do ponto de vista das grandes potências, e especialmente dos EUA, é mais viável negociar e costurar tais acordos vantajosos fora da OMC e das negociações multilaterais da Rodada de Doha, onde enfrentam os países subdesenvolvidos de forma organizada (pela oposição do G-20, liderado por Brasil, Índia e China) (Padula, 2013; UNCTAD, 2007).

Tais acordos visam à manutenção da hegemonia (político-militar, econômica, monetário-financeira e ideológica) dos EUA e à preservação da supremacia e/ou à expansão de suas empresas (detentoras de direitos de propriedade intelectual, marcas etc.) e investidores nessas áreas geográficas. O TPP e o TTIP articulam-se aos acordos militares bilaterais com aliados estratégicos na Ásia-Pacífico (como Japão, Coreia do Sul e Filipinas) e a aliança estratégica no Atlântico Norte (Otan), que permitem presença militar dos EUA predominante nestas áreas. Não se pode perder de vista que os acordos e arranjos de livre-comércio promovidos pelos EUA reforçam ainda mais a hierarquia monetária e financeira internacional baseada no dólar, que resguarda o privilégio de emissor da moeda internacional (sem lastro metálico, mas assentada no poder militar estadunidense).

Vale ressaltar que esses mesmos países sul-americanos da costa do Pacífico - Chile, Peru e Colômbia - têm acordos de livre-comércio com vários países, entre os quais China, Coreia do Sul, Índia, Japão e União Europeia (Padula, 2013). Além disso, formam, junto com o México, a Aliança do Pacífico, um acordo de integração regional neoliberal que pretende predominantemente maior aproximação com as economias da Ásia-Pacífico. São economias pequenas e neoliberais que, por sua inserção histórica, política e econômica, desenvolveram economias baseadas na exploração e na renda de recursos naturais, o que influencia suas instituições e coalizões políticas. Na falta de um processo de integração regional coeso e mutuamente benéfico, liderado por uma potência regional com capacidade política e econômica para levá-lo adiante, essas economias seguem a opção neoliberal.

Estados fortes atuam de acordo com os interesses das suas empresas e da manutenção de assimetrias estruturais no sistema internacional, promovendo acordos e usando sua influência em orga- 
nizações internacionais como forma de legitimar seus interesses, construindo regras que lhes sejam favoráveis. No âmbito global, a busca por acesso facilitado a mercados na área de saúde coloca em foco os países emergentes, visto que as previsões são de aumento da participação de seus mercados nas vendas globais de medicamentos, devido à maior incorporação de contingentes populacionais ao mercado consumidor de produtos de saúde. Assim, esse crescimento leva a mudanças nas estratégias competitivas e de inovação das grandes empresas farmacêuticas globais e de seus Estados fortes. Segundo Vargas (neste volume), baseado em estimativas e dados da IMS Health (companhia estadunidense que fornece informações, serviços e tecnologia para as indústrias do cuidado em saúde), "nos próximos anos cerca de dois terços do crescimento das vendas globais do mercado farmacêutico decorrerão do crescimento dos mercados emergentes". Entre 2012-17, "Estima-se que boa parte desse aumento nos gastos globais com medicamentos estará associada com o crescimento do consumo nos mercados emergentes", com destaque para a China em primeiro lugar, seguida de Brasil, Rússia e Índia. Essas estimativas colocam em evidência a importância dos Brics como mercado.

É importante observar que a indústria farmacêutica sofre um processo de crescente concentração, mas essa não é uma tendência recente. Segundo Almeida (2013: 276),

O mercado global de fármacos é altamente concentrado e polarizado: a) 10 grandes empresas transnacionais produzem cerca de $50 \%$ do total do mercado e as 20 corporações mais importantes estão localizadas nos EUA, Reino Unido, Europa e Japão, sendo que cada uma delas tem, em média, cerca de 100 afiliados em mais de 40 países (dos quais 19 são países em desenvolvimento); b) EUA, Europa e Japão respondem por cerca de $75 \%$ das vendas e, incluindo-se a América Latina, essa porcentagem sobe para 85\%; c) os países desenvolvidos produzem e exportam medicamentos de alto valor agregado e protegidos por patentes e os demais países em desenvolvimento importam esses medicamentos, sendo que alguns produzem genéricos de baixo valor ou medicamentos alternativos e tradicionais. Embora os países desenvolvidos sediem essas corporações, o consumo global de medicamentos evidencia que mesmo em alguns desses países (como nos EUA) permanece um déficit de mercado.

Como parte de um amplo processo de fusões e aquisições da indústria farmacêutica, ao longo dos anos 2000 as grandes empresas transnacionais do setor adotaram novas estratégias que envolvem a convergência entre a indústria farmacêutica e a indústria biotecnológica voltada para a saúde; esse processo foi intensificado nos últimos anos em termos de número de operações de fusões e aquisições e de volume médio de recursos envolvidos em cada operação (Vargas, neste volume). No mesmo sentido, como observamos anteriormente, Reis, Landim e Pieroni (2011) destacam o processo de catching up de China, Índia e Israel na rota biotecnológica, por meio de estratégias lideradas pelo Estado, de incentivos regulatórios, de financiamento e de uma política industrial abrangente. ChaseDunn (2005) considera a liderança biotecnológica dos EUA fundamental na sua estratégia estatal de prolongamento de sua hegemonia, e demonstra como o Estado e suas agências lideraram iniciativas para o setor desde a década de 1980. No mercado de medicamentos biológicos, é digna de registro a problemática relacionada aos biossimilares: embora equivalentes aos genéricos dos produtos de origem sintética, no processo de seu registro e produção não é possível aproveitar o mesmo arcabouço regulatório (Vargas, neste volume). 
A análise de mercado revela uma crescente demanda por produtos biotecnológicos e da nanotecnologia, de maior valor agregado e intensidade tecnológica, o que os torna um meio para as grandes empresas do setor farmacêutico seguirem sua rota de crescimento e concentração de mercado e superarem a tendência de redução dos retornos sobre o investimento (inclusive em P\&D). Segundo Ribeiro e Paiva (neste volume), no período de 2004 a 2011 registrou-se uma tendência de crescimento dos depósitos na área de biotecnologia em saúde. Ao mesmo tempo, a indústria de rota biotecnológica apresenta altas barreiras à entrada, por razões de dificuldades tecnológicas, custo de desenvolvimento e produção, o que tende a levar a um mercado concentrado com menor número de empresas e de empresas de maior porte. ${ }^{19}$

Diante da postura agressiva dos Estados fortes, que buscam abrir mercados e garantir e ampliar direitos de propriedade às suas empresas, e das grandes empresas, o padrão de concentração (e não de reversão) da indústria de fármacos tende a se aprofundar, visto que persistem os mesmos fatores que o consolidaram. As grandes empresas farmacêuticas concentram as atividades e os gastos em P\&D tecnológicos, aproveitando escalas de recursos, encaminhando-se cada vez mais para setores de maior valor agregado e intensidade tecnológica, como biotecnologia e nanotecnologia, dominando também esses mercados. No Brasil, as grandes empresas transnacionais do setor de capital estrangeiro concentram seus esforços de inovação em seus países de origem (Vargas, neste volume). ${ }^{20}$ A atividade de inovação tem importância fundamental na sustentabilidade a longo prazo da indústria farmacêutica, principalmente diante do cenário de esgotamento e expiração de patentes na indústria farmoquímica, associada a um aumento da demanda social e a mudanças no perfil epidemiológico. Vale ressaltar que as atividades produtivas e de P\&D tecnológicos das big pharmas têm como objetivo a obtenção de lucros, o que as impede de considerar demandas relacionadas a doenças específicas de países em desenvolvimento, as chamadas doenças negligenciadas.

No Brasil, a demanda social por produtos biotecnológicos tem exercido crescente impacto sobre os gastos do Ministério da Saúde e, diante da baixa produção nacional, feito aumentar o déficit da balança comercial dos produtos de saúde (na qual o aumento das importações desses produtos é maior do que o de outros medicamentos). O número de depósitos de patentes tem crescido, no entanto registra-se um baixo percentual de depósitos de residentes em relação àqueles de não

${ }^{19}$ Conforme destacam Ribeiro e Paiva (neste volume), “com base em informações do Evaluate Pharma, o crescimento das vendas de biológicos foi de $17 \%$ entre 2002 e 2010 , ao passo que o crescimento médio dos demais produtos farmacêuticos foi de 7\%. Fazendo-se uma projeção com essa taxa de crescimento, espera-se que em 2016 os produtos biotecnológicos representem cerca de $21 \%$ das vendas. O indicador desse crescimento é o aumento do número de registros de novos produtos biológicos: em 2010, o registro de novos produtos biológicos nos Estados Unidos da América (EUA) representou 44\% do total de registros novos, contra 35\% em 2002 (...) Espera-se que os medicamentos biotecnológicos passem de cinco para sete entre os dez produtos farmacêuticos mais vendidos".

${ }^{20}$ Para Almeida (2013: 278), "Não existem evidências de reversão desse padrão de concentração da indústria de fármacos ou de sua atuação agressiva, mesmo nos casos de adoção das flexibilidades previstas na legislação. Como os direitos de propriedade intelectual são harmonizados globalmente, tampouco se comprova a promessa de maior investimento direto nos países que assinaram o acordo para o fortalecimento desses direitos. A escalada dos preços dos medicamentos é objeto de grande preocupação para a maioria dos países, sobretudo aqueles em desenvolvimento e os mais pobres. Alguns países - como Índia, Brasil e Tailândia - têm maior capacidade de produção, entretanto, no caso da produção de genéricos na Índia, com preços bem mais baixos que a posiciona como um dos maiores fornecedores dos países de renda média e baixa, as compras e fusões de indústrias pelas transnacionais já começaram a acontecer". 
residentes, com tendência de declínio da participação dos primeiros no período de 2007 a 2011. O governo, até o início de 2016, vinha tomando uma série de medidas para fomentar a produção da rota biotecnológica no país (Ribeiro \& Paiva, neste volume). No entanto, na evolução do cenário nos últimos anos, a tendência é de que o abastecimento nacional se torne cada vez mais dependente de empresas estrangeiras, de seu domínio produtivo e tecnológico, e consequentemente vulnerável em termos econômicos, políticos e de segurança às ações e interesses dessas empresas e de seus Estados fortes. ${ }^{21}$ A produção física e tecnológica nacional no campo biotecnológico poderia ter importantes impactos sobre os gastos do Ministério da Saúde e a universalização do atendimento à demanda, assim como na autonomia estratégica e redução da vulnerabilidade política e econômica externa do Brasil.

Os crescentes gastos com saúde no Brasil nos próximos anos, impulsionados pela transição demográfica associada ao perfil epidemiológico e envolvendo recursos públicos, trazem enormes oportunidades para a criação de vantagens comparativas dinâmicas no CEIS em atividades de maior valor agregado e intensidade tecnológica, tendo em vista a autonomia estratégica e a segurança em saúde do país. Se não for implementado um processo bem-sucedido de formação do CEIS, o aumento dos gastos tende a se transformar em maior concentração de poder, riqueza e tecnologia nas mãos das big pharmas e de seus Estados de origem, assim como em maior dependência e vulnerabilidade externa do país. Na matriz insumo-produto do CEIS, é importante identificar não só a atual participação de importações e empresas estrangeiras no fornecimento de insumos e bens finais, como também as tecnologias e produtos que tendem a ganhar maior importância no futuro, e que por isso terão maior impacto nas demandas sociais do CEIS.

É importante notar que o domínio expansivo (produtivo, tecnológico e de mercado) das grandes empresas transnacionais lhes aufere a oportunidade de moldar a lógica da saúde e do tratamento de doenças, em busca de lucros extraordinários. Por isso é importante que questões éticas sejam observadas e que formas alternativas de medicina e tratamento não sejam descartadas, especialmente no Brasil.

O amplo mercado e o espaço territorial (continental e marítimo), rico em recursos estratégicos, do Brasil despertam interesses de potências externas. A partir de 2003, na política externa brasileira elegeu-se como espaço prioritário de atuação o seu entorno estratégico, que contém um amplo mercado e recursos estratégicos e, inevitavelmente, se choca contra os interesses de potências externas. O entorno estratégico brasileiro envolve o continente sul-americano e, por nossas características marítimas, se estende até a costa ocidental da África subsaariana e à Antártica. Além disso, sua política externa se direcionou para uma maior projeção ao se aproximar de países da América Central e Caribe, da Comunidade de Países de Língua Portuguesa (CPLP), do Brics (grupo marcado pela heterogeneidade entre seus membros) e, de forma geral, privilegiando a cooperação sul-sul (Fiori, Padula \& Vater, 2013).

\footnotetext{
${ }^{21}$ Em Ribeiro \& Paiva (neste volume) é apresentado "o ranking anual dos dez países de origem com maior número de depósitos dentre as patentes de não residentes no período de 2002 a 2011. Em todos os anos os EUA lideram, com mais que o dobro de patentes que o segundo lugar na lista. Nos segundo e terceiro lugares se alternam Japão e Alemanha (sigla DE), com exceção dos anos 2002 e 2003, em que a França aparece em terceiro lugar. Vale destacar a flutuação na posição da França, que em 2004 cai para o nono lugar e depois gradativamente recupera posição, mas sempre com grande variação. Suíça (CH) e Suécia (NL) apresentam, em geral, um bom posicionamento na classificação. E a China (CN) chega a figurar na lista nos anos de 2007 e 2009".
} 
É importante que o Brasil promova segurança e estabilidade no seu entorno estratégico; políticas de cooperação técnica em favor do desenvolvimento dos países dessa área (e diminuição da vulnerabilidade frente a outras potências) têm um papel fundamental por criarem interdependências e afastarem a influência de potências externas, conflitos e movimentos migratórios conturbadores. Ao mesmo tempo, os países do entorno estratégico brasileiro, ao se desenvolverem de forma interdependente com o Brasil, podem gerar oportunidades de desenvolvimento conjunto (planejado) e um mercado mais amplo para o desenvolvimento e inovação da indústria brasileira da área de saúde (CEIS), sem reproduzir os mesmos padrões predatórios do imperialismo das grandes potências e de suas grandes empresas. Por outro lado, a projeção de poder de potências externas no entorno estratégico brasileiro, como se tem registrado - promovendo acordos de livre-comércio de bens e serviços, acesso a investimentos e a compras governamentais, e garantindo significativos direitos de propriedade intelectual, em favor da supremacia de suas grandes empresas e do aumento da dependência e do subdesenvolvimento desses países -, gera um entorno estratégico inseguro e instável para o Brasil, além da perda de oportunidades de mercados e parcerias para seu avanço industrial e cooperativo nessas áreas.

O Brasil é um país superavitário em suas relações comerciais com todos os países sul-americanos (exceto com a Bolívia, em razão do gás natural), exportador de bens de maior intensidade tecnológica e valor agregado e importador de commodities. E no comércio global é um país deficitário, importador de bens de maior intensidade tecnológica e valor agregado e exportador de commodities - uma relação desfavorável (Padula, 2010, 2011). Assim, o mercado sul-americano apresenta enorme potencialidade e um enorme ativo para o florescimento do CEIS no Brasil, aproveitando sua escala e estabelecendo parcerias mutuamente benéficas com os países da região. O mesmo pode ser dito em favor de uma cooperação no âmbito dos Brics, aproveitando seus crescentes mercados e as possibilidades de parcerias tecnológicas - levando em conta que os países-membros têm muitas características e objetivos similares, mas também muitas diferenças entre si.

No âmbito do Brics, é importante salientar seu potencial para a cooperação política em saúde através das tentativas de reformar o sistema internacional e o papel da OMS (frente à OMC). O Brics tem exercido relevante impacto no âmbito da OMS e na agenda internacional de saúde. Os países Brics têm enormes desafios e interesses comuns na agenda de saúde internacional e têm avançado no sentido de estabelecer uma agenda de cooperação e uma posição comum. É possível encontrar uma linha de temas permanentes nas reuniões de ministros da Saúde do Brics, envolvendo: garantia de acesso universal a medicamentos e serviços de saúde (com Brasil, China e Índia liderando a fabricação de medicamentos e vacinas de baixo custo); fortalecimento do sistema de vigilância sanitária; reforma da OMS; flexibilização do Trips; fortalecimento e acesso à saúde nos países em desenvolvimento; transferências e avanço em tecnologias médias (envolvendo biotecnologia e as TICs, por exemplo); estratégicas para doenças transmissíveis; combate e redução de fatores de risco de doenças não transmissíveis (Silva et al., 2014; Acharya et al., 2014; Padula, 2015).

O Brasil possui 60\% da bacia amazônica e a compartilha com mais sete países sul-americanos e a Guiana Francesa, um território ultramarino francês que comporta bases militares estratégicas. A Amazônia é um espaço rico em biodiversidade (entre outros recursos estratégicos), que desperta 
a cobiça externa. O Brasil e os países da região deveriam ter urgência em articular um amplo mapeamento e registro da biodiversidade amazônica (sua variedade genética), pois esta representa uma potencial oportunidade para a engenharia genética, a biotecnologia e a nanotecnologia, inclusive para o desenvolvimento de fitoterápicos e para a absorção de conhecimentos a partir das comunidades tradicionais.

No entanto, o espaço amazônico é subocupado e subdesenvolvido, mal integrado em termos de infraestrutura aos principais centros econômicos e demográficos da América do Sul. Geram-se, assim, oportunidades para a atuação da biopirataria e permite-se que cientistas de outros países conheçam e registrem as espécies presentes na região em seu proveito, garantindo monopólio e propriedade sob o manto do Trips, em desacordo com a valorização dos conhecimentos tradicionais e com a Convenção sobre Biodiversidade Biológica (esta não ratificada por países detentores de tecnologias de ponta, como é o caso dos EUA). A Organização do Tratado de Cooperação Amazônica (OTCA) deveria ser o meio institucional para a articulação entre os países, sob a liderança brasileira. Mas, historicamente, a OTCA enfrenta enormes dificuldades em despertar interesse dos Estados-membros e em ser revitalizada, tornando-se um potencial espaço de penetração de interesses externos na região, inclusive por intermédio de organizações não governamentais que atuam de maneira funcional e sob o financiamento de interesses estrangeiros (Guimarães, 2005). O financiamento de projetos produtivos predatórios, combinados com infraestrutura de corredores de exportação, busca articular os recursos da região aos mercados globais, principalmente da bacia do Pacífico. Ao mesmo tempo, os recursos do pré-sal apresentam oportunidades em termos de geração de recursos financeiros que podem ser utilizados na formação do CEIS. E a formação de mão de obra voltada para engenharia química não absorvida na exploração do pré-sal pode representar um ativo importante. No entanto, tanto o Atlântico sul quanto a Amazônia representam um enorme desafio à segurança territorial brasileira, diante da ação permanente de grandes potências nessas regiões, inclusive a atuação militar dos EUA por meio do estabelecimento de bases militares (na Colômbia, por exemplo), da execução de exercícios militares periódicos e da reativação de sua IV Frota do Atlântico Sul.

O Brasil é o maior país da América Latina, a maior potência tropical e do hemisfério sul. Assim, apesar de sua política externa de projeção de poder ser pacífica e baseada na cooperação, o Brasil inevitavelmente desafiará os interesses de grandes potências em diferentes tabuleiros geopolíticos, o que possivelmente o levará a se envolver em disputas e conflitos de interesses políticos com potências externas (e suas coalizões). Por isso, o país deve se preocupar com sua autonomia estratégica e com sua segurança (no sentido defensivo), estabelecendo um poder dissuasório capaz de repelir ameaças e pressões externas. Em razão da proximidade de interesses políticos e da similaridade de potenciais adversários, os principais parceiros potenciais do Brasil se encontram na América do Sul (Mercosul e Unasul), na África e entre os países do Brics. Uma região onde se concentram recursos e oportunidades, mas onde também estão presentes outras potências, com seus próprios interesses e conflitos, e com suas alianças e apoios, dentro de cada um dos países desse mesmo entorno estratégico. As regiões ricas em recursos estratégicos e com mercados pujantes tendem a ser crescentemente incorporadas como fronteiras geopolíticas da expansão capitalista, sofrendo assédio de grandes potências e suas grandes empresas (privadas e estatais), por serem áreas que contêm mercados e recursos estratégicos 
para o funcionamento da economia, para a expansão das grandes empresas transnacionais e para o desenvolvimento econômico e militar das potências tradicionais e das emergentes.

É ilustrativo mencionar alguns casos que demonstram conflitos potenciais e vulnerabilidades. Não podemos ignorar que todos os setores associados ao CEIS têm sido usados como ferramentas de ação geopolítica das potências centrais. Não nos referimos aqui às ações pontuais da Usaid, Agência dos Estados Unidos para o Desenvolvimento Internacional, ou às agências europeias na África ou mesmo na América Latina e Ásia, em países mais pobres. As disputas de propriedade intelectual e compras governamentais são objeto de impasses nas negociações comerciais multilaterais.

O conflito em torno da liberdade de trânsito de medicamentos genéricos e dos direitos de patentes é um caso ilustrativo. As autoridades europeias realizaram sistemáticas apreensões de medicamentos genéricos em seus portos, restringindo a circulação desses bens essenciais à saúde humana, cujas patentes das grandes empresas multinacionais não encontram direito de proteção nos países de origem e de destino, mas somente direito de propriedade intelectual na Europa. Como os medicamentos se encontravam em trânsito e não se destinavam ao mercado europeu, não caberia a aplicação de direitos de propriedade das empresas farmacêuticas titulares de patentes na Europa, e nem se poderia alegar danos a estas - uma vez que tais patentes ou sequer foram registradas nos países de origem e destino ou expiraram, e que eventualmente o comércio se dá baseado em princípios de saúde pública que prevalecem sobre a propriedade intelectual. Além de violar o Trips e a Declaração de Doha, tais ações arbitrárias e unilaterais violam o artigo V do Gatt, que prevê liberdade de trânsito.

Em 2008, no porto de Roterdã, alegando questões de propriedade intelectual, as autoridades holandesas apreenderam uma carga do genérico Losartan produzido na Índia e destinado ao Brasil. Tal episódio demonstra o grau de acirramento dessa disputa ${ }^{22}$ e como as autoridades europeias colocam a questão da propriedade intelectual acima da saúde pública de outros povos, ou seus interesses políticos e econômicos acima dos interesses socioeconômicos de outros países. Outros carregamentos detidos em portos europeus tinham como destino Nigéria, Vanuatu, Peru, Colômbia, Equador, México e Venezuela. Os carregamentos continham medicamentos essenciais para o tratamento de HIV, doenças coronarianas, esquizofrenia, Alzheimer, colesterol e hipertensão. Obviamente, os atingidos são as populações dos países em desenvolvimento e dos menos desenvolvidos.

A importância dos atrativos portos dos países europeus nas rotas comerciais internacionais - em razão de sua posição geográfica favorável e de seu vigor econômico - aufere a esses países posições importantes em rotas comerciais de bens estratégicos, o que, por sua vez, lhes confere maior poder

\footnotetext{
22 "As apreensões de medicamentos em trânsito têm sido objeto de polêmico debate em diversas instâncias internacionais. O confisco, ocorrido em 4 de dezembro de 2008, de $570 \mathrm{~kg}$ de Losartan Potassium, princípio ativo usado para a produção de medicamentos para o tratamento de hipertensão arterial, recebeu particular destaque. O produto, avaliado em $€ 55$ mil, havia sido negociado entre a empresa indiana Dr. Reddy's e a brasileira EMS e estava a caminho do Brasil, mas não alcançou seu destino final. Apesar de o fármaco não ser protegido por patente nem na Índia nem no Brasil, a carga foi confiscada na Holanda, país onde a multinacional MerckSharp\&Dohme (MSD) detém sua patente em conjunto com a DuPont. A MSD enviou uma carta à Dr. Reddy's por meio de seus advogados em 24 de dezembro de 2008, informando a empresa da retenção e exigindo a renúncia da carga, sob ameaça de destruição do produto. Segundo nota de esclarecimento da Merck do Brasil, a carga retornou à Índia por solicitação da Dr. Reddy's, após permanecer retida por 36 dias no porto de Roterdã" (Reis \& Faria, 2010).
} 
de veto político à circulação desses bens estratégicos/essenciais. Ao mesmo tempo, gera vulnerabilidade nos países dependentes dessas rotas comerciais e bens, caso não possam ou não busquem rotas alternativas.

O caso da influenza A (H1N1) parece-nos emblemático da vulnerabilidade que pandemias podem causar a países que não contem com uma produção autônoma de medicamentos e vacinas. Diante do surto, as potências hegemônicas garantiram em primeiro lugar o atendimento de medicamentos às suas populações, e o governo brasileiro encontrou dificuldades em suprir as necessidades nacionais. No caso de fornecimento de vacinas, as empresas priorizavam contratos já estabelecidos e, diante de pedido da OMS de conceder vacina grátis aos países pobres, concederam-na apenas parcialmente ou a negaram (foi o caso da Novartis). Os casos da influenza A (H1N1) e da SARS demonstraram que, diante de pandemias, as soluções predominantes não são de caráter comunitário (coletivo) e as grandes potências atuavam para garantir seus interesses nacionais, sua estabilidade interna e segurança nacional.

\section{Panorama Nacional: dinâmica de mercado e universalização do acesso à saúde com equidade}

A Constituição de 1988 trouxe a integração, sob a denominação de Seguridade Social, do conjunto das "ações de iniciativa dos poderes públicos e da sociedade destinados a assegurar os direitos relativos à saúde, à previdência e à assistência social", com previsão de fontes específicas para seu financiamento. No texto constitucional se afirma que "a saúde é direito de todos e dever do Estado, garantido mediante políticas sociais e econômicas que visem à redução do risco de doença e outros agravos e ao acesso universal e igualitário às ações e serviços para sua promoção, proteção e recuperação".

Esse componente político também permitiu uma atuação maior do Estado na economia, sem as constantes ameaças dos economistas do mercado. O desmantelamento da União Soviética e a derrota da alternativa socialista deram lugar à vitória do neoliberalismo e às ideias do Estado mínimo, e com elas à tentativa de desmonte de qualquer noção de proteção social.

Ainda assim o setor Saúde movimenta, em média, 8,7\% do PIB (IBGE, 2012), o que evidencia sua importância econômica. Em uma perspectiva economicista, o aumento dos gastos em saúde tem um potencial de incremento no crescimento econômico por seus efeitos multiplicadores, induzindo investimentos em outros setores. Incorporando-se às dimensões sociais do desenvolvimento, como proposto em Sen (2000), o setor ganha ainda mais relevância com a inclusão da mortalidade infantil e expectativa de vida ao nascer como variáveis a serem consideradas na análise das condições de vida de determinado país.

Outra noção a ser acrescentada é a de que uma redução da mortalidade não se acompanha necessariamente de uma redução da incidência de problemas de saúde; pelo contrário, aumenta o número de sobreviventes que estarão sujeitos à ocorrência de problemas de saúde adicionais. Dessa forma, o viés econômico de um debate sobre saúde deve partir da premissa de que quanto mais saúde um povo tem, de mais assistência médica ele precisa. Como corolário, quanto maior o gasto em saúde hoje, maior ele será amanhã. 
Segundo Marco Antonio Vargas (neste volume),

A existência de um modelo de atenção à saúde pautado pelo acesso universal, associada às mudanças nos padrões demográficos e epidemiológicos no país, tem ampliado consideravelmente a demanda por serviços de saúde e pressionado os gastos públicos com medicamentos, principalmente no que se refere à crescente incorporação de terapias baseadas nos avanços da biotecnologia e nanomedicina nas compras do Sistema Único de Saúde (SUS). A busca de competências nessas novas plataformas tecnológicas assume um caráter ainda mais estratégico para o país ao possibilitar o aumento da produção doméstica de medicamentos e fármacos que representam uma parcela significativa do déficit na balança comercial do CEIS

Fica evidente uma forte demanda por produtos e serviços de saúde, a qual deve aumentar, independentemente do direcionamento ideológico do governo. Gadelha e Costa (2013a) elencam diversas iniciativas que, mediante o aumento do uso do poder de compra do Estado, podem contribuir para o desenvolvimento tecnológico em saúde:

1) parcerias para o desenvolvimento produtivo objetivando a transferência de tecnologia entre empresas farmacêuticas nacionais ou estrangeiras e laboratórios oficiais com acesso às compras governamentais;

2) aumento do dispêndio público na compra direta de medicamentos e outros produtos;

3) expansão do Programa Farmácia Popular;

4) associação da estratégia de imunização com a de desenvolvimento tecnológico nacional, fazendo uso do poder de compra do Estado para ter acesso às tecnologias das empresas líderes mundiais.

Gadelha e Costa (2013b: 26) advogam ainda o "uso estratégico, do ponto de vista do desenvolvimento nacional, do poder de compra do Estado, e não apenas de forma racionalmente econômica".

Em sua análise da indústria de base mecânica, eletrônica e de materiais, Maldonado e Oliveira (neste volume) também veem as compras públicas como um agente responsável na indução do setor.

O caráter indutor do desenvolvimento das compras governamentais é tão evidente que, recorrentemente, estas aparecem como um dos impasses nas negociações da Rodada de Doha da Organização Mundial do Comércio.

Outro aspecto ressaltado por Vargas (neste volume) é que,

De maneira geral, as macrotendências, associadas tanto à política de atenção à saúde como ao perfil sociodemográfico e epidemiológico, ressaltam a importância da incorporação das novas plataformas tecnológicas da biotecnologia e da nanotecnologia nas práticas assistenciais em saúde. Tais tendências representam um grande desafio para a base produtiva em saúde do país, seja no tocante ao atendimento das demandas do sistema nacional de saúde, que deve contemplar os princípios de universalidade, integralidade e equidade, seja pela intensificação das pressões competitivas de um sistema produtivo claramente intensivo em conhecimento.

Vargas ainda elenca algumas macrotendências associadas a mudanças nos padrões de demanda, de regulação e de tecnologia: 1) mudanças associadas à política de atenção à saúde - desospitalização, 
medicina personalizada, valorização da qualidade de vida, modelos de financiamento público/privado; 2) mudanças associadas ao perfil socioeconômico e demográfico - envelhecimento populacional, novos padrões de vida, impacto de mudanças ambientais, urbanização; 3) impacto das novas plataformas tecnológicas na biotecnologia e nanotecnologia - biologia molecular (genômica, proteômica etc.), bioinformática e bioimagem, nanobiotecnologia, ciências de materiais, sistemas de informação de alto desempenho e neurociência.

A forma como essa demanda crescente será suprida está diretamente vinculada ao próprio padrão de desenvolvimento e inserção internacional a que o Brasil almeja, tanto como potência regional quanto como membro de uma coligação de potências em nível global (Brics). Nesse sentido, é preciso observar:

1) a capacidade nacional de ofertar os produtos e serviços necessários não apenas para atender à demanda doméstica, mas também para concorrer internacionalmente com a produção das demais potências, que pode inclusive ser um vetor estratégico de nossa inserção geopolítica; e

2) a concorrência internacional das transnacionais fomentadas inclusive pelas estratégias geopolíticas de seus países-sede.

No tocante à capacidade de atender à demanda nacional, é preciso ainda definir setores estratégicos nos quais o desenvolvimento tecnológico é imprescindível para a segurança do país. A capacidade de produção autônoma, ou reversão do parque industrial - que permita uma produção em larga escala e em curto período de vacinas, antibióticos e quaisquer outros medicamentos necessários ao combate a epidemias potencialmente globais -, é fundamental.

Além dos economicistas, é preciso incorporar outros aspectos quando se trata de abordar o problema. O já citado caso da influenza A (H1N1), em que os países avançados garantiram primeiro o atendimento a suas populações e o governo brasileiro encontrou dificuldades em suprir as necessidades nacionais, parece-nos emblemático. A epidemia do ebola de 2014 acendeu um sinal de alerta. Leigh Phillips coloca a questão de maneira bem clara:

Mas o ebola é um problema que não tem sido resolvido porque quase não há dinheiro envolvido em sua solução. É uma doença não lucrativa. (...)

Em tal situação, já não teríamos sequer que discutir se a prevenção da malária, do sarampo ou da poliomielite mereceria maior prioridade; poderíamos focalizar tanto as doenças renomadas quanto as negligenciadas, ao mesmo tempo. Não há garantias de que abrir a torneira do financiamento público produza imediatamente um bom resultado, mas, no momento, as empresas farmacêuticas privadas sequer tentam. (...)

Nossa preocupação aqui não está meramente no fato de que a recusa das big pharma a se envolverem em pesquisa e desenvolvimento de vacinas e antibióticos para as doenças tropicais negligenciadas é grotescamente imoral ou injusta, mas no fato de que a produção de uma abundância de novos produtos e serviços potenciais, que de outra forma poderiam beneficiar nossa espécie e expandir o reino da liberdade humana, são bloqueados devido à letargia do livre mercado e à falta de ambição. 
Concentrar-se em uma vacina ou remédio é fundamental. Contudo, fazer isso sem também dar atenção à deterioração da saúde pública e da infraestrutura geral em toda a África ocidental, bem como às condições econômicas mais abrangentes que contribuem para a maior probabilidade de surtos de doenças zoonóticas como o ebola, é, na melhor das hipóteses, usar um balde para escoar a água de um barco furado e afundando. (Phillips, 2014, tradução nossa)

Não obstante, Garret (2013) alerta para os riscos do duplo uso da pesquisa em biotecnologia. Ela traz, inclusive, o caso de uma pesquisa de 2011 com o vírus H5N1 que fez com que este patógeno, que em princípio infectaria apenas aves, pudesse afetar seres humanos. Naquele momento, pouco menos de seiscentas pessoas haviam sido contaminadas pelo vírus, mas com uma taxa de mortalidade de 59\% - a autora lembra que a gripe espanhola, que matou mais de 50 milhões, tinha uma taxa de mortalidade de 2,5\%. Garret acrescenta a informação de que o governo da Indonésia se recusou a compartilhar as amostras do H5N1 que se espalhava em suas fronteiras, alegando que as farmacêuticas ocidentais tentariam patentear quaisquer descobertas para obter altos lucros vendendo vacinas e medicamentos a altos preços para países pobres.

Garret lembra que não haverá consenso sobre o duplo uso entre os cientistas e os especialistas em segurança, exemplificando com o vigoroso debate sobre a destruição do vírus da varíola 35 anos após sua erradicação. Não haveria clareza sobre os benefícios da pesquisa em biotecnologia, mas os seus defensores alegam que seu potencial é tão revolucionário quanto o da tecnologia da informação, cuja revolução está em curso. Uma ação agressiva contra o duplo uso poderia estancar o desenvolvimento tecnológico, tanto mais porque tal contenção incluiria o controle excessivo sobre o fluxo de informações na internet, por exemplo.

O que isso significa é que os líderes políticos não devem esperar por clareza e informação perfeita, nem correr para desenvolver controles restritivos, nem confiar na autorregulação científica. Em vez disso, eles devem aceitar que a revolução da biologia sintética está aqui para ficar, monitorá-la de perto e tentar tomar as medidas apropriadas para conter alguns dos seus riscos mais óbvios, como o vazamento acidental ou liberação deliberada de organismos perigosos. (Garret, 2013, tradução nossa)

Ou seja, para além das questões econômicas envolvidas em uma análise geopolítica, a segurança estratégica do país deve ser uma variável central no processo de decisão relacionado às políticas públicas do CEIS. O grau de autonomia de um país depende de sua capacidade de resistir a pressões externas. Na Estratégia Nacional de Defesa elaborada pelo governo brasileiro, em que são abordadas as questões de segurança nacional, está registrado que

Todas as instâncias do Estado deverão contribuir para o incremento do nível de Segurança Nacional, com particular ênfase sobre: (...) as medidas de defesa química, bacteriológica e nuclear, a cargo da Casa Civil da Presidência da República, dos Ministérios da Defesa, da Saúde, da Integração Nacional, das Minas e Energia e da Ciência e Tecnologia, e do GSI-PR, para as ações de proteção à população e às instalações em território nacional, decorrentes de possíveis efeitos do emprego de armas dessa natureza; (...) a execução de estudos para viabilizar a instalação de um centro de pesquisa de doenças tropicais para a região amazônica, a cargo dos Ministérios da Defesa, da Ciência e Tecnologia, da Saúde e órgãos de saúde estaduais e municipais; (...) medidas de defesa contra pandemias. (Brasil, 2008: 65) 
Ainda que o foco do debate esteja dirigido para a saúde, a pesquisa e o desenvolvimento para construir capacidade de resposta, tanto para os casos de conflitos (bélicos ou não) quanto para epidemias ou pandemias, podem gerar como externalidade um aumento da capacidade dissuasória do país por meio de descobertas que permitam o domínio sobre processos de elaboração de armamento químico ou biológico.

Em países emergentes como o Brasil a política industrial é necessária. Os países retardatários que encaram com determinação e coragem processos de catching up fazem uso de instrumentos públicos para promover o seu desenvolvimento econômico. As políticas liberais defendidas pelos países mais desenvolvidos constituem suas estratégias de hegemonia e não devem ser vistas pelos países subdesenvolvidos como noções ideais de orientação política (Chang, 2002).

Além disso, deve-se observar ainda a concorrência internacional das empresas transnacionais fomentadas inclusive pelas estratégias geopolíticas de seus países-sede. Particularmente na indústria farmacêutica temos um oligopólio internacional e poucos países têm capacidade de desenvolvimento de um complexo industrial associado. Na base mecânica, eletrônica e de materiais, temos a tecnologia de ponta diretamente associada a sinergias com setores da indústria bélica.

O big business farmacêutico passa atualmente por uma reformulação do seu modelo de negócios, em resposta à crise do modelo anterior relacionada, pelo lado da oferta, ao menor lançamento de novas moléculas no mercado (queda da produtividade de P\&D) diante da expiração conspícua de patentes dos produtos mais rentáveis (blockbusters) e à maior concorrência com os medicamentos genéricos. Pelo lado da demanda, a maior exigência por custo-efetividade por parte dos pagadores de saúde, públicos ou privados, médicos e pacientes, em relação aos produtos inovadores oferecidos pela indústria farmacêutica é outro fator de pressão sobre o business (Burrill \& Company, 2013).

A crise financeira global de 2008 deu início a um processo de endividamento dos Estados, que se viram obrigados a intervir nos bancos, seguradoras e também em empresas não financeiras para mitigar os efeitos desastrosos da crise que afetou principalmente as finanças públicas dos países da tríade EUA, Europa Ocidental e Japão. Em outras partes do mundo, como China, Índia e Israel, novos players farmacêuticos, focados em genéricos, estão emergindo e ganhando cada vez mais participação no mercado mundial (Reis, Landin \& Pieroni, 2011).

O big business farmacêutico, em resposta, promoveu um amplo processo de consolidação, com enormes fusões e aquisições até o ponto em que as empresas já estão se tornando grandes demais para serem compradas. E, além disso, passaram a focar em novos nichos de mercado restringindo seu portfólio a poucos produtos de alto valor agregado, consumidos em pequenos volumes e utilizados em tratamentos muito caros (Burril \& Company, 2013).

Outras estratégias foram adotadas na tentativa de mitigar as perdas do business nesse novo cenário, como, por exemplo, uma atuação litigiosa mais agressiva para estender o período das patentes, estímulo para o uso off label de medicamentos e o forte lobby para acordos internacionais ligados a propriedade industrial e intelectual.

O novo modelo de negócios tem por base os avanços da biologia molecular e conjuga tratamentos com características mais personalizadas. Uma estratégia muito recente tem sido o investimento em 
um nicho conhecido como doenças órfãs, doenças raras que afetam um número muito pequeno de pessoas (Guimarães, 2014). Esse novo modelo está no cerne das preocupações de Carlos Diegues em seu artigo "Seleção artificial" (2008). O business está se voltando cada vez mais para um público de alta renda, negligenciando a realidade da saúde mundial e os problemas que afetam a maioria da população mundial.

Há um crescente distanciamento entre os interesses da saúde como um bem público e os interesses comerciais das grandes corporações farmacêuticas que comandam o processo de inovação. As doenças e medicamentos pouco rentáveis são negligenciados, não obstante afetarem grande número de pessoas e serem extremamente importantes para a medicina (Guimarães, 2014).

São exemplos desse fenômeno as doenças negligenciadas e o problema das superbactérias, resistentes aos antibióticos existentes. O retorno da tuberculose em sua forma fatal em regiões em que havia sido erradicada nos anos 1950, Europa e EUA, representa um grave retrocesso. Os antibióticos não recebem investimentos significativos há três décadas, por não serem rentáveis (Homedical, 2012). Os interesses da saúde e os interesses dos mercados de capitais estão em caminhos opostos, e a contradição levada ao absurdo poderia resultar no surgimento do Homo ricus de Carlos Diegues.

Esse modelo é, a longo prazo, incompatível com um modelo de saúde pública universal como o Sistema Único de Saúde (SUS), em um país de 200 milhões de habitantes. Custo-efetividade e tratamentos mais eficazes, que busquem a cura das doenças e não a sua cronicidade, são fundamentos sólidos para a conformação de um complexo industrial da saúde inovador, porém com o foco mais voltado para os reais interesses da saúde da população como um todo e menos para obter lucros extraordinários.

O setor Saúde, por ser based on science, requer a articulação das políticas científicas, tecnológicas e industriais, que devem, juntas, ser capazes de estruturar um sistema de inovação (infraestrutura e recursos para $\mathrm{P} \& \mathrm{D}$ ) e um sistema produtivo (base industrial) que atenda às necessidades de saúde do país, principalmente do SUS. ${ }^{23}$

Desde 2003, o governo brasileiro promove o fomento ao complexo industrial da saúde brasileiro, impulsionado pelas políticas adotadas pelo Ministério da Saúde, por intermédio de sua Secretaria de Indústria, Ciência e Tecnologia (Brasil, 2003). A política de desenvolvimento industrial promovida pelo Ministério da Saúde, como exemplo do que se pretende com o uso de políticas industriais, está estruturando o setor de biotecnologia brasileiro. A prioridade da política industrial brasileira para a saúde até o início de 2016 era a construção de uma indústria de biotecnologia moderna, aproveitando oportunidades de catching up que se darão no período 2014-2020, quando as patentes dos principais medicamentos biotecnológicos expirarão. Com a instituição de um sistema regulatório pró-desenvolvimento industrial e o uso do poder de compra do Estado como indutor do processo (e garantidor de uma demanda mínima) - combinando o capital privado nacional (capacidade empresarial) e o apoio financeiro do Estado (financiamento com custo compatível com o equilíbrio

\footnotetext{
${ }^{23}$ Segundo Vargas e colaboradores (2013: 34), "Em âmbito internacional a indústria farmacêutica é um oligopólio diferenciado baseado nas ciências, sendo a diferenciação de produtos pautada no esforço de P\&D por um lado, e na força de marketing, por outro".
} 
econômico-financeiro do projeto) -, chega-se a um equilíbrio complexo entre a oferta nacional de produtos biotecnológicos e as vantagens obtidas para o sistema nacional de saúde, que deverá se beneficiar de preços mais baratos. O uso do instrumento das PDPs e a liderança das grandes empresas farmacêuticas brasileiras de capital nacional, que estão capitalizadas e propensas a diversificar seus investimentos, representam para o país a abertura de um novo campo profissional.

Uma iniciativa com esse grau de complexidade, e status de política de Estado, requer continuidade política. Construir um setor de biotecnologia não é tarefa trivial e, portanto, para que a política obtenha sucesso é imprescindível o acompanhamento do desempenho competitivo das novas empresas no âmbito das políticas públicas de fomento industrial.

Todavia, não basta criar um setor e fomentar empresas, esse é apenas o primeiro passo de um processo de longuíssimo prazo. É preciso promover a competitividade do setor e inseri-lo numa trajetória de progresso tecnológico, que resulte para o país em novas instituições que possam dar suporte ao esforço de pesquisa, desenvolvimento e inovação esperados para o sucesso do projeto; ou, do contrário, a indústria se tornará obsoleta e um passivo oneroso para o país.

A política industrial não será bem-sucedida sem uma coordenação eficiente entre as diversas instituições envolvidas, públicas e privadas. O conceito de complexo industrial se aplica muito bem ao setor Saúde pelas suas diversas interfaces com as diversas áreas do conhecimento a serviço da medicina humana. A indústria ligada à saúde, seja no segmento de fármacos, em suas duas plataformas de conhecimento principais, a química e a biologia, seja no segmento de equipamentos médicos, compõe com o sistema de inovação um tecido extenso e complexo, que requer mão de obra altamente qualificada.

A indústria de saúde é intensivamente baseada em conhecimento científico e depende, competitivamente, da inovação para sobreviver. O desenvolvimento de uma indústria nacional de saúde no Brasil depende do concomitante desenvolvimento de um complexo industrial, científico e tecnológico em bases nacionais.

A aposta na biotecnologia faz parte de uma trajetória da indústria farmacêutica brasileira iniciada com a lei dos genéricos e a criação da Agência Nacional de Vigilância Sanitária, a Anvisa. A partir de 2003, sobre as bases da Política Industrial, Tecnológica e de Comércio Exterior, as mudanças implementadas passaram a produzir efeitos e as empresas brasileiras de capital nacional tiveram que se adequar à nova institucionalidade. Com a criação do Profarma, programa de apoio do BNDES ao complexo industrial da saúde, as empresas brasileiras puderam ter acesso aos recursos financeiros para os investimentos demandados pela nova legislação (Vargas, neste volume).

Ao longo da última década, o mercado farmacêutico brasileiro cresceu de modo significativo graças ao fortalecimento do segmento de medicamentos genéricos e ao maior acesso da população ao consumo de medicamentos. Em 2013, o mercado brasileiro passou à sexta posição mundial, chegando à casa dos R $\$ 50$ bilhões (IMS Health, 2013).

A introdução dos genéricos foi uma oportunidade para a indústria brasileira e ampliou o mercado consumidor pelos efeitos redistributivos da redução de preços, impulsionada, por sua vez, 
pelo aumento da concorrência e pelos menores custos para o lançamento de produtos genéricos no mercado (Gomes et al., 2014).

As empresas farmacêuticas de capital nacional conseguiram aproveitar as oportunidades, e o seu desempenho pode ser verificado pelo aumento de market share no mercado nacional - de 33\% em 2003 para 57\% em 2013 - e pelo aumento dos investimentos em inovação, que, segundo a Pesquisa de Inovação realizada pelo Instituto Brasileiro de Geografia e Estatística (IBGE), passaram de 0,5\% da receita em 2003 para 2,7\% em 2011, ao passo que a média da indústria brasileira ficou estagnada. Nesse mesmo período, o número de empresas de capital nacional entre as dez maiores se elevou de uma para quatro companhias (Gomes et al., 2014). Entretanto, segundo Quental e colaboradores,

embora necessário, o incentivo aos genéricos, por si só, não incentiva os fármacos, uma vez que as empresas nacionais de genéricos não se dispõem a entrar nesse segmento, bastante diferente daquele em que atuam até o momento.

O incentivo aos genéricos também não toca na questão da inovação, do desenvolvimento de novas moléculas, o cerne da competição na arena mais nobre e lucrativa da indústria farmacêutica. Ao contrário, não há nem mesmo a possibilidade de inovação incremental em genérico, pois ele deixaria de ser "cópia idêntica" do medicamento de referência, se bem que a própria produção do genérico constitua uma inovação para a empresa produtora.

Não se pode apostar que se incentivando os medicamentos e as empresas de genéricos estas se engajariam no desenvolvimento de atividades de P\&D voltadas para o desenvolvimento de novas moléculas - poucas têm essa intenção. A arena competitiva é outra, os fatores críticos de sucesso são outros e as empresas de genéricos não se sentem nem capacitadas nem atraídas a atuar nessa outra arena. Os incentivos para a inovação têm que ser específicos. (Quental et al., 2008: 625-626)

Em função das mudanças estruturais que ocorrem no país, ligadas ao processo de transição demográfica e epidemiológica, a perspectiva de crescimento do mercado farmacêutico brasileiro se mantém bastante promissora. Segundo o IMS Health (2013), a taxa de crescimento médio anual deverá se situar numa faixa de $13 \%$ a $16 \%$ até 2018 , tornando o Brasil o quarto maior mercado mundial.

Inúmeras companhias brasileiras (Bionovis, Libbs, Orygen, Cristália e Biomm) estão se constituindo e se estruturando, em razão da atuação estatal para promover o desenvolvimento da biotecnologia moderna no Brasil em três grandes frentes: o uso do poder de compra do Estado, a regulação e o apoio financeiro diferenciado (Ibac Brasil, 2013).

Refletindo essa prioridade, o BNDES criou em 2013 o subprograma Profarma Biotecnologia. Nos últimos dois anos foram contratados 11 projetos, totalizando um apoio de $\mathrm{R} \$ 1,3$ bilhão. A carteira total de projetos do Profarma, que apoiou o complexo industrial da saúde de 2003 até julho de 2014, foi, nesse período, de R \$ 4,8 bilhões, em 116 operações.

No segmento de equipamentos médicos, na última década o crescimento do mercado brasileiro também atingiu taxas de dois dígitos. Há uma enorme defasagem no atendimento à população, portanto há uma demanda reprimida que deverá crescer a partir do momento que os hospitais começarem 
a investir. O país importa no setor de equipamentos médicos $68 \%$ do que consome internamente, e, no entanto, a indústria brasileira seria capaz de atender a 95\% das necessidades (Abimo, 2014).

As políticas públicas para o setor devem fortalecer o mercado nacional, que é $60 \%$ público, e incentivar a indústria para que se torne mais competitiva e melhore sua inserção internacional. O país exportou cerca de US\$ 800 milhões em 2013, mas teve déficit comercial de US\$ 4,1 bilhões.

A concorrência que efetivamente ameaça a indústria brasileira se dá com as grandes multinacionais, que são apoiadas pelos seus respectivos Estados de origem, onde estão fincadas as raízes de seu capital. O caso recente de intervenção da opinião pública e do governo ingleses na tentativa de compra da britânica AstraZeneca pela americana Pfizer mostrou, claramente, como os interesses nacionais contam e influenciam nas transações e negócios empresariais (Armitage, 2014). Está em jogo a preservação dos empregos e das atividades mais estratégicas da indústria ligadas à pesquisa, desenvolvimento e inovação (PD\&I) no país. Além disso, pesou o fato de a empresa ter sido objeto de apoio de políticas públicas e ter recebido recursos públicos, importantes para sua trajetória, que provavelmente seriam desperdiçados, do ponto de vista nacional, caso a aquisição pela Pfizer se concretizasse.

Os recursos de que o país precisa dispor para estruturar e organizar um complexo industrial da saúde dinâmico requer a formação e treinamento de mão de obra qualificada e a constituição de uma infraestrutura (capital fixo) adequada. A descoberta de uma nova entidade terapêutica ou o desenvolvimento de um novo equipamento médico para diagnóstico requer pesquisa científica básica. E o financiamento desses investimentos, que envolve grande montante de recursos, na maioria dos países desenvolvidos concentra-se em fontes públicas. Em países subdesenvolvidos e periféricos como o Brasil, a importância do investimento público é ainda mais fundamental, pelas especificidades do setor Saúde e pela própria condição do subdesenvolvimento.

Após a descoberta e o registro de patente de uma nova molécula é necessário submetê-la aos testes pré-clínicos e clínicos até a obtenção de registro ou autorização da autoridade sanitária para sua comercialização. Como base para a evolução dessa indústria requer-se o desenvolvimento de um sistema de inovação (Freeman, 1995) que permita que se realize no Brasil a P\&D das empresas brasileiras. Pelas razões tratadas na primeira seção deste capítulo, no âmbito da economia política internacional, esses objetivos estão circunscritos ao desenvolvimento nacional.

A indústria brasileira pode encontrar novos campos de investimento em nichos de mercado e desenvolver competências com seus próprios esforços em áreas em que os países desenvolvidos não têm interesse ou vantagens comparativas, como é o caso das doenças negligenciadas e da biodiversidade.

Nos últimos dez anos a indústria farmacêutica brasileira de capital nacional está traçando uma trajetória de forte crescimento. As empresas desse setor estão capitalizadas e têm maior capacidade financeira para investir. Numa divisão de trabalho entre setor público e privado, o Estado provê um arranjo de políticas públicas favorável que ajude a promover a indústria, e o setor privado nacional deve ser capaz de liderar os investimentos na expansão da indústria e apoiar o desenvolvimento da capacidade de P\&D no Brasil, demandando, crescentemente, esses serviços internamente (Quental et al., 2013). 
Um dos principais problemas para o desenvolvimento do setor de serviços de P\&D no Brasil está na falta de demanda das empresas brasileiras. Em cada etapa do pipeline há barreiras de todas as ordens - operacionais, institucionais, técnicas, profissionais etc. - e em todas elas há problemas estruturais de fundo que inviabilizam o pleno desenvolvimento do país como um todo (Quental et al., 2013).

Os diagnósticos para nossos problemas estão relativamente bem mapeados e são conhecidos; a maior dificuldade está na capacidade de organização para promover as reformas estruturais que permitam ao Brasil dar um salto e resgatar integralmente sua dívida social.

Nossa particularidade como principal potência tropical nos permite avançar em setores em que temos, além das vantagens comparativas no sentido clássico, o que poderíamos chamar de vantagens estratégicas. Há um conjunto de enfermidades chamadas de doenças tropicais, que apenas os países tropicais enfrentam e sobre as quais os laboratórios das grandes farmacêuticas atreladas às necessidades das potências do hemisfério norte não realizam pesquisas; mesmo quando o fazem, a pesquisa de ponta encontra-se no Brasil, como é o caso da doença de Chagas.

O desenvolvimento de produtos para o segmento de doenças negligenciadas permitiria ao Brasil responder a uma demanda real interna e também aumentar sua inserção internacional, tanto econômica quanto política. Econômica, por promover um aumento de exportações nesse setor. E política porque permite aumentar a capacidade do Brasil de, por meio de cooperações internacionais, se contrapor à hegemonia imposta aos países tropicais e do hemisfério sul, contribuindo para a conformação de um cenário internacional multipolar.

Ademais, a biodiversidade é um ativo brasileiro único. Ela representa uma vantagem comparativa para o país, e transformá-la em riqueza pelos e para os brasileiros é um enorme desafio. A legislação brasileira (medida provisória 2.186-16, de 23/08/2001) que regulava o acesso, o aproveitamento econômico e a repartição dos benefícios com as comunidades provedoras e detentoras de conhecimentos tradicionais, a título de proteger os direitos dessas comunidades acabou por inviabilizar o desenvolvimento de produtos por empresas brasileiras.

Além disso, a legislação não impedia a exportação de elementos da biodiversidade brasileira para estudo, pesquisa e desenvolvimento de produtos fitoterápicos por empresas estrangeiras. Muitos projetos de empresas brasileiras foram cancelados por falta de incentivos para investir; as comunidades provedoras, por sua vez, não se beneficiaram com a exploração de conhecimentos sobre a biodiversidade por elas detidos; e a biopirataria, especialmente a realizada por interesses estrangeiros, capazes de se apropriar dos benefícios da biodiversidade brasileira, permanece incólume.

Os obstáculos criados pela regulação inviabilizaram a P\&D de novos fármacos e também o desenvolvimento do setor de fitoterápicos. Nesse segmento, a baixa e decrescente participação desses produtos no mercado farmacêutico brasileiro é um exemplo inequívoco de desperdício econômico.

Os mercados no mundo nos quais os fitoterápicos mais crescem são exatamente os mercados dos países mais desenvolvidos - EUA, Alemanha e Japão, onde nossos produtos de maior valor agregado têm menor espaço. Se conseguirmos, de forma justa e equilibrada, estruturar uma indústria brasileira de fitoterápicos competitiva, o Brasil poderá se tornar um dos principais produtores e fornecedores de produtos fitoterápicos para o mercado mundial. 
As dificuldades inerentes ao arcabouço regulatório da MP 2.186-16 levaram à mudança da legislação. Em 20 de maio de 2015 foi decretada e sancionada a lei n. 13.123, que alterou o marco regulatório de acesso, repartição de benefícios e aproveitamento econômico da biodiversidade brasileira. A nova lei substitui a necessidade de autorização prévia por um cadastro, estabelece critérios mais objetivos para a repartição de benefícios e regulariza o passivo criado pela legislação anterior. Com essas medidas espera-se tornar o ambiente regulatório brasileiro mais favorável à P\&D e produção de novos fármacos e fitoterápicos no país.

Outro fator de extrema relevância é o recente movimento de consolidação entre as grandes farmacêuticas, que tem gerado uma especialização setorial e criado monopólios por enfermidade. Exemplo disso foi a recente troca de ativos entre a Novartis e a GSK, duas das maiores farmacêuticas do mundo (Copley \& Sandle, 2012). Obviamente que esses acordos não se operam apenas nos planos empresariais, mas estão também inseridos dentro das estratégias nacionais dos países-sede. A concentração não apenas em um país, mas em uma única empresa, coloca o Brasil em uma situação de fragilidade que deve ser evitada a todo custo.

Essas questões podem ser mais bem elucidadas por meio de uma análise mais detalhada dos aspectos econômicos. O mercado farmacêutico mundial, em 2012, atingiu a cifra de US\$ 962 bilhões. A crise global de 2008 impactou fortemente a indústria mundial, que passou a olhar com mais atenção para os mercados emergentes, que têm crescido a taxas bastante expressivas. Entre as principais causas do maior dinamismo dos mercados emergentes destacam-se a elevação da renda, o envelhecimento da população, o maior peso das doenças crônicas degenerativas no perfil epidemiológico e o fortalecimento dos sistemas públicos de saúde (Vargas, neste volume).

Tabela 1 - Mercado mundial por regiões - 2008-2012 (em US\$ bilhões)

\begin{tabular}{|r|r|r|r|r|r|r|}
\hline Ano & $\begin{array}{c}\text { Receita } \\
\text { Mundo }\end{array}$ & $\begin{array}{c}\text { América do } \\
\text { Norte }\end{array}$ & Europa & Japão & $\begin{array}{c}\text { Ásia, África, } \\
\text { Austrália }\end{array}$ & $\begin{array}{c}\text { América } \\
\text { Latina }\end{array}$ \\
\hline 2008 & 773 & 312 & 248 & 77 & 91 & 47 \\
\hline 2009 & 808 & 322 & 248 & 90 & 103 & 46 \\
\hline 2010 & 856 & 335 & 245 & 97 & 127 & 53 \\
\hline 2011 & 956 & 347 & 265 & 111 & 165 & 67 \\
\hline 2012 & 962 & 366 & 231 & 115 & 173 & 77 \\
\hline TCAC & $5,6 \%$ & $4,1 \%$ & $-1,7 \%$ & $10,8 \%$ & $17,5 \%$ & $13,4 \%$ \\
\hline
\end{tabular}

TCAC - Taxa de crescimento anual composta.

Fonte: IMS Health, 2013.

A International Federation of Pharmaceutical Manufacturers \& Associations apresentou alguns dados interessantes sobre a indústria mundial de medicamentos (IFPMA, 2013). Com base nos dados disponíveis nesse documento, elaboramos a Tabela 2 selecionando os países em que vendas no mercado doméstico de medicamentos fossem superiores a US\$ 7 bilhões ou as exportações ultrapassassem US\$ 4 bilhões. Os dados permitem observar que há países que, mesmo com um mercado 
interno modesto, conseguiram uma posição relevante no cenário internacional. O Brasil faz parte de um grupo de países que conjugam déficit comercial bastante relevante no setor com um volume pouco relevante de exportações. Os EUA, por exemplo, apresentam um déficit comercial significativo e ao mesmo tempo grande volume de exportações.

Tabela 2 - Vendas farmacêuticas. Países selecionados - 2011

\begin{tabular}{|c|c|c|c|c|c|c|c|}
\hline País & $\begin{array}{c}\text { Vendas } \\
\text { farmacêuticas } \\
\text { domésticas } \\
\text { US\$ bilhões }\end{array}$ & $\begin{array}{l}\text { Vendas farma- } \\
\text { cêuticas } \\
\text { domésticas } \\
\text { US\$ per capita }\end{array}$ & $\begin{array}{c}\text { Vendas } \\
\text { farmacêuticas } \\
\text { domésticas } \\
\text { \% gasto em saúde }\end{array}$ & $\begin{array}{l}\text { Exportações } \\
\text { farmacêuticas } \\
\text { US\$ milhões }\end{array}$ & $\begin{array}{l}\text { Importações } \\
\text { farmacêuticas } \\
\text { US\$ milhões }\end{array}$ & $\begin{array}{c}\text { Balança } \\
\text { comercial } \\
\text { farmacêutica } \\
\text { US\$ milhões }\end{array}$ & $\begin{array}{l}\text { Importações/ } \\
\text { vendas } \\
\text { domésticas + } \\
\text { exportações }\end{array}$ \\
\hline Alemanha & 55,148 & 671,00 & 14,60 & $61.926,00$ & $44.793,50$ & $17.132,50$ & $38,26 \%$ \\
\hline Argentina & 7,582 & 186,00 & 20,10 & 784,50 & $1.743,80$ & $-959,30$ & $20,84 \%$ \\
\hline Austrália & 13,268 & 587,00 & 10,50 & $3.446,00$ & $9.959,60$ & $-6.513,60$ & $59,59 \%$ \\
\hline Bélgica & 8,507 & 791,00 & 15,70 & $45.278,50$ & $32.171,00$ & $13.107,50$ & $59,81 \%$ \\
\hline Brasil & 28,718 & 146,00 & 12,70 & $1.134,60$ & $6.189,10$ & $-5.054,50$ & $20,73 \%$ \\
\hline Canadá & 26,057 & 759,00 & 13,60 & $5.212,10$ & $11.860,10$ & $-6.648,00$ & $37,93 \%$ \\
\hline China & 66,863 & 50,00 & 18,70 & $2.580,30$ & $9.970,10$ & $-7.389,80$ & $14,36 \%$ \\
\hline Cingapura & 0,716 & 138,00 & 6,90 & $4.864,70$ & $1.452,10$ & $3.412,60$ & $26,02 \%$ \\
\hline Coreia do Sul & 14,796 & 306,00 & 19,60 & 895,10 & $3.548,90$ & $-2.653,80$ & $22,62 \%$ \\
\hline Dinamarca & 2,437 & 437,00 & & $7.735,80$ & $3.275,20$ & $4.460,60$ & $32,20 \%$ \\
\hline Espanha & 28,009 & 603,00 & 19,20 & $13.391,00$ & $13.282,30$ & 108,70 & $32,08 \%$ \\
\hline Estados Unidos & 337,100 & $1.077,00$ & 12,40 & $35.342,20$ & $62.447,20$ & $-27.105,00$ & $16,77 \%$ \\
\hline França & 48,664 & 771,00 & 14,90 & $35.482,00$ & $23.660,70$ & $11.821,30$ & $28,12 \%$ \\
\hline Grécia & 9,347 & 821,00 & 30,80 & $1.196,00$ & $4.046,90$ & $-2.850,90$ & $38,38 \%$ \\
\hline Holanda & 9,380 & 563,00 & 10,70 & $15.047,60$ & $11.880,30$ & $3.167,30$ & $48,63 \%$ \\
\hline Índia & 15,643 & 13,00 & 21,00 & $8.079,10$ & $1.359,40$ & $6.719,70$ & $5,73 \%$ \\
\hline Israel & 1,978 & 262,00 & 10,80 & $7.003,20$ & $1.519,50$ & $5.483,70$ & $16,92 \%$ \\
\hline Itália & 34,630 & 570,00 & 16,40 & $16.960,30$ & $17.987,90$ & $-1.027,60$ & $34,87 \%$ \\
\hline Japão & 127,377 & $1.007,00$ & 21,20 & $3.353,50$ & $19.049,40$ & $-15.695,90$ & $14,57 \%$ \\
\hline México & 12,978 & 113,00 & 18,30 & $1.579,40$ & $4.212,50$ & $-2.633,10$ & $28,94 \%$ \\
\hline Polônia & 11,257 & 294,00 & 29,70 & $2.076,20$ & $5.662,10$ & $-3.585,90$ & $42,47 \%$ \\
\hline Reino Unido & 38,334 & 614,00 & 16,50 & $31.902,40$ & $24.478,40$ & $7.424,00$ & $34,85 \%$ \\
\hline Rússia & 20,653 & 145,00 & 24,20 & 297,60 & $12.730,80$ & $-12.433,20$ & $60,77 \%$ \\
\hline Suécia & 6,597 & 699,00 & 13,10 & $9.916,70$ & $4.485,30$ & $5.431,40$ & $27,16 \%$ \\
\hline Suíça & 7,629 & 991,00 & 10,40 & $52.662,20$ & $19.652,30$ & $33.009,90$ & $32,60 \%$ \\
\hline Turquia & 10,242 & 139,00 & 20,60 & 531,80 & $4.510,90$ & $-3.979,10$ & $41,87 \%$ \\
\hline Venezuela & 8,449 & 287,00 & 56,60 & 39,20 & $2.645,70$ & $-2.606,50$ & $31,17 \%$ \\
\hline Média & 35,273 & 482,96 & 18,43 & $13.656,22$ & $13.280,56$ & 375,67 & $32,16 \%$ \\
\hline
\end{tabular}

Fonte: IFPMA, 2013. 
O mercado brasileiro relacionado ao complexo industrial da saúde, que inclui o mercado farmacêutico e de equipamentos médicos, alcançou em 2013 a marca de R $\$ 70$ bilhões, crescendo a uma taxa média de $12 \%$ ao ano nos últimos cinco anos.

Tabela 3 - Mercado brasileiro. Complexo industrial da saúde - 2009-2013 (em R\$ milhões)

\begin{tabular}{|c|c|c|c|c|c|c|}
\hline Setor & 2009 & 2010 & 2011 & 2012 & 2013 & TCAC \\
\hline Farmacêutico & 33.090 & 38.563 & 40.329 & 44.876 & 50.000 & $11 \%$ \\
\hline Equipamentos médicos & 10.920 & 12.850 & 13.950 & 16.770 & 19.070 & $15 \%$ \\
\hline $\begin{array}{l}\text { Complexo industrial da } \\
\text { saúde }\end{array}$ & 44.010 & 51.413 & 54.279 & 61.646 & 69.070 & \\
\hline
\end{tabular}

TCAC - Taxa de crescimento anual composta.

Fontes: Abiquif, 2014; Abimo, 2014.

No Brasil, as causas desse crescimento estão associadas à introdução dos medicamentos genéricos no mercado, ao aumento do gasto público em saúde e à elevação do poder de compra de parcela mais pobre da população. Pelo lado da indústria, as empresas brasileiras de capital nacional souberam aproveitar o boom e foram paulatinamente ganhando participação no mercado de saúde nacional. No mercado de genéricos, em 2012, das cinco maiores empresas no mercado brasileiro, em faturamento, quatro são empresas brasileiras de capital nacional. Ademais, no âmbito das farmacêuticas de modo geral, de acordo com o ranking "Maiores e melhores" elaborado pela revista Exame, das cinco maiores empresas farmacêuticas instaladas no país, três são estrangeiras: a norte-americana Pfizer e as suíças Novartis e Roche (Maiores..., 2014).

Tabela 4 - Participação das empresas farmacêuticas de capital nacional no mercado brasileiro de genéricos

\begin{tabular}{|l|l|c|r|r|r|r|}
\hline \multicolumn{1}{|c|}{ Laboratório } & Origem & \multicolumn{1}{|c|}{$08 / 11$} & \multicolumn{1}{c|}{$08 / 12$} & Crescimento & Participação \\
\hline 1 & Grupo EMS & Brasil & 2.551 .832 .490 & 3.504 .897 .747 & $37,35 \%$ & $33 \%$ \\
\hline 2 & Grupo Sanofi Aventis & França & 2.592 .710 .209 & 3.100 .610 .851 & $19,59 \%$ & $29 \%$ \\
\hline 3 & Eurofarma & Brasil & 506.971 .912 & 783.912 .795 & $54,63 \%$ & $7 \%$ \\
\hline 4 & Hypermarcas & Brasil & 414.615 .785 & 664.399 .598 & $60,24 \%$ & $6 \%$ \\
\hline 5 & Aché & Brasil & 405.645 .271 & 509.177 .849 & $25,52 \%$ & $5 \%$ \\
\hline 6 & Pfizer & EUA & 312.298 .752 & 454.884 .747 & $45,66 \%$ & $4 \%$ \\
\hline 7 & Novartis & Suíça & 294.056 .052 & 382.053 .849 & $29,93 \%$ & $4 \%$ \\
\hline 8 & Prati Donaduzzi & Brasil & 105.181 .876 & 254.732 .959 & $142,18 \%$ & $2 \%$ \\
\hline 9 & Sankyo & Japão & 178.200 .713 & 156.119 .638 & $-12,39 \%$ & $1 \%$ \\
\hline 10 & Merck Serono & Suíça & 107.737 .972 & 128.711 .999 & $19,47 \%$ & $1 \%$ \\
\hline Total 10 primeiros & & 7.469 .251 .033 & 9.939 .502 .032 & $33,07 \%$ & $94 \%$ \\
\hline Mercado genérico total & & 7.820 .190 .784 & 10.531 .847 .213 & $34,68 \%$ & $100 \%$ \\
\hline
\end{tabular}

Elaboração: Sindusfarma, 2014. Fonte: IMS Health (PMB Plus, 2013). 
Esse grande crescimento, não obstante o bom desempenho das empresas brasileiras, principalmente no segmento farmacêutico de genéricos, foi acompanhado por um grave desequilíbrio externo. Em sua análise de importações e exportações, publicada no documento Conta-Satélite de Saúde Brasil 2007-2009, o IBGE evidencia a vulnerabilidade do país.

$\mathrm{Na}$ Tabela 5 se demonstra um importante déficit comercial no setor Saúde, o qual se acentua nos setores de produtos farmoquímicos, medicamentos para uso humano e aparelhos e instrumentos para usos médico-hospitalares.

Tabela 5 - Balança comercial de bens e serviços de saúde, segundo os produtos. Brasil - 2007-2009

\begin{tabular}{|c|c|c|c|c|c|c|c|c|c|}
\hline \multirow{3}{*}{ Produtos } & \multicolumn{9}{|c|}{ Balança comercial de bens e serviços de saúde (1.000.000 $\mathrm{R} \$$ a preços correntes) } \\
\hline & \multicolumn{3}{|c|}{2007} & \multicolumn{3}{|c|}{2008} & \multicolumn{3}{|c|}{2009} \\
\hline & Exportação & Importação & Saldo & Exportação & Importação & Saldo & Exportação & Importação & Saldo \\
\hline TOTAL & 355.672 & 315.217 & 40.455 & 414.295 & 408.534 & 5.761 & 355.653 & 360.847 & -5.194 \\
\hline TOTAL DA SAÚDE & 2.230 & 11.572 & -9.342 & 2.592 & 13.671 & -11.079 & 3.014 & 14.898 & -11.884 \\
\hline $\begin{array}{l}\text { Produtos } \\
\text { farmoquímicos }\end{array}$ & 187 & 2.089 & -1.902 & 223 & 2.728 & -2.505 & 288 & 2.610 & -2.322 \\
\hline $\begin{array}{l}\text { Medicamentos } \\
\text { para uso humano }\end{array}$ & 817 & 5.704 & -4.887 & 1.042 & 6.445 & -5.403 & 1.368 & 7.252 & -5.884 \\
\hline $\begin{array}{l}\text { Medicamentos } \\
\text { para uso } \\
\text { veterinário }\end{array}$ & 311 & 870 & -559 & 383 & 1.100 & -717 & 404 & 1.312 & -908 \\
\hline $\begin{array}{l}\text { Materiais para } \\
\text { usos médicos, } \\
\text { hospitalares e } \\
\text { odontológicos }\end{array}$ & 294 & 174 & 120 & 310 & 192 & 118 & 321 & 204 & 117 \\
\hline $\begin{array}{l}\text { Aparelhos e } \\
\text { instrumentos } \\
\text { para usos } \\
\text { médicos, } \\
\text { hospitalares e } \\
\text { odontológicos }\end{array}$ & 573 & 2.705 & -2.132 & 569 & 3.175 & -2.606 & 563 & 3.484 & -2.921 \\
\hline $\begin{array}{l}\text { Serviços de } \\
\text { atendimento } \\
\text { hospitalar }\end{array}$ & 48 & 30 & 18 & 65 & 31 & 34 & 70 & 36 & 34 \\
\hline
\end{tabular}

Fonte: elaboração própria com base em IBGE, 2012.

A vulnerabilidade brasileira é apresentada de forma evidente na Tabela 6 . 
Tabela 6 - Déficit comercial do complexo industrial da saúde. Brasil - 2003-2012 (em US\$ milhões FOB)

\begin{tabular}{|c|c|c|c|c|c|c|}
\hline Ano & Biológicos & Medicamentos & $\begin{array}{c}\text { Insumos } \\
\text { Farmacêuticos }\end{array}$ & $\begin{array}{c}\text { Cadeia } \\
\text { Farmacêutica }\end{array}$ & EMHO & Total \\
\hline 2003 & 410 & 844 & 697 & 1.951 & 629 & 2.580 \\
\hline 2004 & 492 & 976 & 829 & 2.297 & 662 & 2.959 \\
\hline 2005 & 465 & 1.110 & 862 & 2.437 & 877 & 3.314 \\
\hline 2006 & 642 & 1.345 & 870 & 2.857 & 1.179 & 4.036 \\
\hline 2007 & 724 & 2.046 & 1.297 & 4.068 & 1.639 & 5.707 \\
\hline 2008 & 1.111 & 2.208 & 1.665 & 4.984 & 2.155 & 7.138 \\
\hline 2009 & 1.273 & 2.126 & 1.667 & 5.066 & 2.232 & 7.298 \\
\hline 2010 & 2.284 & 2.533 & 1.825 & 6.642 & 3.034 & 9.676 \\
\hline 2012 & 2.154 & 2.893 & 1.657 & 6.703 & 3.353 & 10.056 \\
\hline
\end{tabular}

Fontes: Aliceweb/MDIC (Brasil, 2014); Abiquifi, 2014.

Em outra análise interessante, o IBGE apresenta a participação das importações na oferta total de cada um dos setores (Tabela 7).

Tabela 7 - Participação das importações na oferta total. Brasil - 2007-2009

\begin{tabular}{|l|c|c|c|}
\hline \multicolumn{1}{|c|}{ Produtos } & \multicolumn{2}{c|}{ Participação das importações na oferta total } \\
\hline & 2007 & 2008 & 2009 \\
\hline TOTAL DA SAÚDE & $4,50 \%$ & $4,80 \%$ & $4,60 \%$ \\
\hline Produtos farmoquímicos & $82,50 \%$ & $87,10 \%$ & $82,40 \%$ \\
\hline Medicamentos para uso humano & $10,00 \%$ & $10,00 \%$ & $9,80 \%$ \\
\hline Medicamentos para uso veterinário & $17,30 \%$ & $20,80 \%$ & $22,20 \%$ \\
\hline $\begin{array}{l}\text { Materiais para usos médicos, hospitalares e } \\
\text { odontológicos }\end{array}$ & $5,90 \%$ & $5,60 \%$ & $5,30 \%$ \\
\hline $\begin{array}{l}\text { Aparelhos e instrumentos para usos médicos, } \\
\text { hospitalares e odontológicos }\end{array}$ & $22,40 \%$ & & \\
\hline
\end{tabular}

Fonte: IBGE, 2012. 
Identifica-se aí uma relevante vulnerabilidade comercial, particularmente no setor de farmoquímicos. Vargas, neste volume, também identifica o "déficit estrutural na balança comercial dos segmentos de medicamentos, fármacos e hemoderivados" e chama atenção para um dado particularmente preocupante na balança comercial brasileira de antibióticos, que é um déficit no segmento de medicamentos e no de insumos farmacêuticos.

Neste volume, Maldonado e Oliveira também indicam um crescente déficit na balança comercial de equipamentos e materiais, inclusive com risco de extinção de empresas. Aliás, esse quadro se agrava nos produtos com maior intensidade tecnológica.

Em contraponto às nossas fragilidades, é preciso atentar também para as potencialidades. Gadelha e Costa (2013a, 2013b), Vargas (2013) e Maldonado e Oliveira (neste volume) afirmam que um dos principais vetores que podem alavancar o CEIS é o poder de compra do Estado. Entretanto, a descentralização das compras públicas no atual modelo do SUS dilui sobremaneira essa capacidade. Portanto, é necessária a concentração do poder de compra de modo a reforçar o caráter indutor dessa ação governamental.

Não se pode também olvidar as próprias vantagens comparativas brasileiras naturais e construídas. O Brasil está na fronteira tecnológica da neurociência graças às pesquisas desenvolvidas no Instituto Internacional de Neurociências de Natal Edmond e Lily Safra, na Fundação Osvaldo Cruz e nos institutos de Bioquímica Médica e de Biofísica Carlos Chagas Filho, ambos da Universidade Federal do Rio de Janeiro, entre outras instituições. Ademais, o país tem um potencial natural para o desenvolvimento da biotecnologia, e o crescimento exponencial da economia do petróleo tem permitido a formação de um número de engenheiros químicos muito além da capacidade de absorção pelo setor petroleiro. O próprio estudo da IFPMA (2013) mostra instituições brasileiras como absorvedoras de transferências de tecnologia.

Por fim, o Brasil faz parte de uma coligação de potências com um peso cada vez maior na geopolítica mundial, o Brics, e tem papel fundamental na estratégia de integração da América do Sul via Unasul e Mercosul. As ações do país devem ser sempre coordenadas dentro de uma estratégia comum com esses parceiros. Eventuais necessidades de atendimento à demanda interna que a oferta não seja capaz de suprir devem ser atendidas preferencialmente por nações inseridas nessas parcerias estratégicas.

\section{Próximos Vinte Anos}

Nos próximos anos, o sistema interestatal tende a se tornar cada vez mais competitivo e conflituoso, com a expansão das potências emergentes - China e Índia -, a retomada, pela Rússia, de uma política de expansão, a crescente oscilação política e divisão da Europa, os surgimentos de Estados, coalizões de Estados e grupos políticos contestadores na periferia, e a política de manutenção e prolongamento da atual ordem hegemônica por parte dos EUA. Por isso, deve-se acelerar a busca por acesso a mercados e recursos estratégicos na periferia do sistema, incluindo cada vez mais a América do Sul e a África (Fiori, 2013). 
A hegemonia dos EUA será cada vez mais contestada e os estadunidenses se lançarão, cada vez mais, em uma estratégia de expansão para prolongar essa hegemonia. Temos uma Europa débil e sob a tutela dos EUA (e seu braço militar da Otan) e, ao mesmo tempo, com forte dependência energética da Rússia. Esta última, junto com Brasil, China, Índia e África do Sul, tende a se articular diante da perda de poder relativo dos EUA - e China e Rússia já têm ganhado espaço político e se articulado no Conselho de Segurança da ONU, e firmado importantes acordos bilaterais (inclusive nos campos energético e de comércio e financiamento em moedas locais) (Escobar, 2014).

Independentemente de suas escolhas, o Brasil enfrentará a crescente projeção de poder estatal, especialmente dos EUA e da China, e a crescente competição de grandes empresas transnacionais no seu entorno estratégico, apoiados em grandes acordos por acesso facilitado a recursos estratégicos e mercados, envolvendo liberalização comercial de bens e serviços, compras governamentais, liberdade e proteção de investimentos, garantia e ampliação de direitos de propriedade e especialmente de propriedade intelectual. Esse quadro levará a desafios progressivos na possibilidade de exportações e internacionalização de empresas brasileiras, podendo até mesmo prejudicar o processo de formação do CEIS, caso este almeje contar com a ampla escala de um mercado regional sul-americano e com o mercado africano. Além disso, continuará o processo de crescentes fusões e aquisições e trocas de ativos para segmentação e especialização de mercados, nos quais as big pharmas se expandirão e concentrarão, cada vez mais, o mercado e a propriedade intelectual, e avançarão na rota biotecnológica e na nanotecnologia. Em todo caso, a importância das indústrias biotecnológica e nanotecnológica continuará crescendo, a indústria de equipamentos e materiais continuará sendo fundamental e as tecnologias da informação e comunicação (TICs) serão crescentemente importantes. Assim, as escolhas políticas do Estado brasileiro serão fundamentais para sua autonomia estratégica e segurança sanitária, ou, por outro lado, para sua vulnerabilidade política e econômica no sistema internacional (Vargas, neste volume).

Sobretudo na agenda de saúde internacional, as grandes potências continuarão a agir, pressionadas por suas grandes empresas, para a manutenção de regras no sistema internacional que sejam favoráveis à continuidade da expansão e concentração de mercado. Trata-se, portanto, de uma atuação incisiva e contrária a ações que não sejam condizentes com as regras de manutenção do status quo, ou as desafiem seja por questões de saúde, sociais, humanitárias ou protecionistas, ou de desenvolvimento, autonomia estratégica e segurança nacional. Tal quadro sugere a tendência de crescentes conflitos em questões de saúde no âmbito internacional, relativos a comércio de bens e serviços, investimentos e direitos de propriedade intelectual. No âmbito das organizações internacionais Conselho de Segurança da ONU, OMC, OMS -, as grandes potências continuarão se articulando em torno dos seus interesses e marginalizando políticas contrárias.

Os mercados emergentes tendem a ganhar importância nos próximos anos. A política de inserção desses países nos acordos e negociações, no mercado e nos investimentos internacionais será fundamental (Vargas, neste volume). Do contrário, seu crescimento econômico e seus crescentes mercados podem se transformar em maior dependência e vulnerabilidade externa, e não em autonomia estratégica, transferindo recursos públicos para grandes empresas transnacionais sediadas em países centrais. No âmbito do Brics, China e Índia têm levado adiante estratégias bem-sucedidas de 
catching up na rota biotecnológica. Negociando de forma conjunta, os países emergentes alcançam maior poder de barganha em negociações internacionais e maior força para desafiar os interesses de potências externas e de grandes empresas, o que revela o importante papel de blocos de integração. Embora nos próximos vinte anos os EUA devam continuar sendo a principal potência global (em termos políticos, culturais, militares, tecnológicos e monetário-financeiros), a crescente competição entre potências concorrentes certamente abrirá espaço para negociações políticas que busquem favorecimentos em termos de investimentos, financiamentos e transferências tecnológicas.

O fato é que, nos próximos vinte anos, se o Brasil almeja um projeto de desenvolvimento autônomo e de projeção externa, especialmente para o seu entorno estratégico, no qual a formação do CEIS avance dentro da concepção de autonomia estratégica e segurança sanitária, inevitavelmente colidirá com as estratégias e os interesses de grandes potências e de potências emergentes, e de suas grandes empresas, abrindo espaços para cooperação e gerando conflitos. Tal posicionamento, ainda que condizente com a tradição pacífica da política externa brasileira, demanda a defesa de reformas nas regras e instituições do sistema internacional (e algumas vezes não as cumprir em favor da soberania nacional) e uma postura ativa do Estado na regulação interna e na formação de arranjos institucionais em prol da produção física e científico-tecnológica, estabelecendo políticas que não correspondem ao interesse das grandes empresas e de seus Estados. No âmbito da política interna, além de políticas específicas para o CEIS, uma política macroeconômica que privilegie metas de crescimento e emprego, impulsionada pelo papel do investimento público, pode ser um importante alicerce. E no âmbito das relações externas, o Brasil não poderá deixar de constituir um poder dissuasório condizente com a dimensão e as ambições do país, onde há uma oportunidade de articulação entre o desenvolvimento da base industrial de defesa e do CEIS, especialmente se a formação de ambos continuar sendo vislumbrada nos documentos estratégicos e políticas do governo.

A volta às políticas vigentes nos anos 1990 nos levaria a uma política econômica cada vez mais restritiva e subordinada aos mercados internacionais e suas grandes empresas. A política externa privilegiaria uma relação próxima e colaborativa com as grandes potências, os grandes investidores e empresas internacionais, atuando de forma colaborativa em relação às regras e organizações internacionais, de forma coerente com a agenda política internacional pautada pelos Estados fortes. Tal postura se apoiaria na construção de instituições e regras favoráveis aos interesses do capital privado internacional, com o objetivo de atraí-lo. E, assim, tornaria o país cada vez mais vulnerável e dependente das suas relações exteriores, ao sabor dos interesses das grandes potências e de seus investidores privados. Tais opções não levariam à constituição do CEIS e, no máximo, as empresas brasileiras se dedicariam a atividades de montagem ou de menor valor agregado, baseadas em inovações incrementais.

No entanto, também temos a possibilidade de que governos com projetos de autonomia estratégica esbarrem em constrangimentos internos e externos (articulados entre si), ou seja, na falta de capacidade política para implementá-los. Isso pode resultar até mesmo em uma política macroeconômica que mescle elementos restritivos e expansivos em prol do crescimento econômico, restringindo a atuação do investimento público e do planejamento estatal, tornando-se óbices à construção do CEIS e configurando um quadro de crescente dependência tecnológica, financeira e comercial, apesar do 
incremento da economia e do setor produtivo. No âmbito da política de defesa e da política externa, apesar da intenção de projeção de poder, a falta de capacidade e de bases internas tende a interferir na capacidade de projeção e influência no sistema internacional.

Como já dito aqui, Estados fortes abrem mercados para garantir e ampliar direitos de propriedade às suas empresas e as grandes empresas aprofundam o padrão de expansão e concentração (e não de reversão) da indústria de fármacos sob controle das big pharmas. Assim, independentemente do grupo político que o governe, o Brasil não tem como se isolar desse cenário. E as prospecções que fazemos para o próximo período devem considerar o dilema popular "cabeça de sardinha ou rabo de baleia". Nesse sentido, para projetar os cenários futuros do país, assumimos que, no tocante à autonomia estratégica e à segurança em saúde, o Estado brasileiro poderá ser conduzido em três circunstâncias diferentes:

1) Na direção da construção de um CEIS baseado nos princípios de autonomia estratégica e segurança em saúde como parte de segurança nacional, articulado ao desenvolvimento da indústria militar, buscando reformas no sistema internacional, formando alianças contestadoras da atual ordem hegemônica e projetando-se para o seu entorno estratégico. Tal postura política em relação ao CEIS (e sua articulação com a indústria militar) implica resistir às pressões que virão dos interesses das multinacionais atraídas pelo pujante mercado de saúde brasileiro, e, portanto, enfrentar as articulações das grandes potências em favor de suas empresas e da expansão e concentração do seu capital. Essa política de formação do CEIS demandaria uma política macroeconômica voltada para o desenvolvimento econômico, liderada pelo investimento público e pelos mecanismos de financiamento estatais.

2) Continuidade das políticas atuais - uma política de boas intenções e baixa efetividade - que procura, com a permanência dos problemas identificados e o agravamento de alguns deles, fomentar a indústria nacional de saúde nos ramos dos genéricos e impulsionar inovações incrementais, com a ampliação do parque industrial em setores com tecnologias já difundidas e crescente participação tecnológica, produtiva e comercial de empresas transnacionais, mas sem capacidade de se aprofundar e avançar nas tecnologias de maior valor agregado e intensidade tecnológica. Ainda assim, há a possibilidade de explorar o potencial das doenças negligenciadas (em razão de as margens de lucro não serem atraentes para o capital internacional) e da biodiversidade. Este cenário pode se combinar com uma continuidade na política macroeconômica restritiva baseada em metas de inflação, tendo a realização de superávits primários e a taxa de juros como variáveis de ajuste, não concretizando a devida atenção à área de saúde e o correspondente financiamento. Ou com alguns elementos de uma política macroeconômica mais voltada para o desenvolvimento.

3) Mudanças políticas em favor de maior abertura econômica, participação mínima do Estado e colaboração com as regras propostas pelas grandes potências globais nas organizações internacionais, tentando estabelecer um marco regulatório com o objetivo de atrair o capital privado estrangeiro e as grandes empresas globais, aprofundando a inserção histórica do país na divisão internacional do trabalho baseada na produção e comercialização de commodities de baixo valor agregado, com crescente vulnerabilidade externa e dependência política. Ainda assim, neste cenário, também há a possibilidade de explorar o potencial das doenças negligenciadas, mas não a biodiversidade, setor em que se abrirá cada vez mais 
espaço para participação do capital estrangeiro. Neste quadro, as políticas macroeconômicas se tornariam ainda mais restritivas, com maiores metas de superávit primário e juros, e a capacidade de financiamento do setor Saúde ficaria muito reduzida.

As projeções para as próximas duas décadas dependem das escolhas concernentes às políticas internas e à política externa a serem feitas pelos governos brasileiros que cheguem ao poder. Estas, por sua vez, dependem das coalizões políticas internas, da distribuição de poder no sistema internacional e da economia política global. No Brasil, ainda não temos uma política de Estado, e sim de governo, o que significa que as escolhas de políticas podem mudar de acordo com a coalizão política que chegar ao poder, sem qualquer garantia de continuidade.

\section{Conclusão}

O CEIS, por sua importância social, econômica, tecnológica, política e de segurança, deve ser constituído com base em uma estratégia liderada pelo Estado brasileiro, colocando como questão central a busca pela autonomia estratégica e pela segurança sanitária, como parte da segurança nacional. Uma questão-chave é a possibilidade de firmar parcerias com Estados no seu entorno estratégico e no âmbito dos Brics, aproveitar o mercado regional sul-americano e africano, e trabalhar maior articulação entre o CEIS e a base industrial de defesa, nos campos produtivo e tecnológico.

As potências tradicionais e as potências emergentes tratam a indústria de saúde como um setor estratégico. Potências emergentes como a China e a Índia têm mostrado um processo de catching up bem-sucedido; EUA e China mostram a importância da integração entre o complexo industrial-militar e a indústria de saúde.

Ao mesmo tempo:

1) O sistema interestatal tem passado por uma aceleração permanente de sua competição, com as potências tradicionais e emergentes buscando cada vez maior acesso e controle de mercados e recursos - processo que não deixa escolha ao Brasil e ao seu entorno estratégico quanto a se envolver ou não nessa crescente disputa, restando-lhes a opção quanto a participar de forma ativa ou subordinada.

2) A indústria de saúde global tem registrado uma continuidade na sua tendência à concentração de propriedade, produção de tecnologias de ponta (patentes) e comércio nas mãos das big pharmas, as quais têm cada vez mais se direcionado para os setores de biotecnologia e nanotecnologia, nos seus processos de fusões e aquisições. Além disso, tal processo tem sido reforçado pela troca de ativos entre empresas que objetivam a segmentação e a especialização de mercados.

3) Os mercados emergentes (especialmente dos Brics) tendem a apresentar a maior taxa de crescimento nos últimos anos.

4) Como resultante das três afirmações anteriores, as grandes potências tradicionais e as principais potências emergentes têm construído grandes acordos para garantir acesso a mercados. Os EUA têm procurado incluir outros temas além dos comerciais - como acesso a mercados e compras governamentais e propriedade intelectual -, o que tende a 
concentrar cada vez mais mercados nas mãos de suas empresas, e isso já alcança o entorno estratégico brasileiro. Nesse sentido, ganha destaque a conclusão do acordo Trans-Pacific Partnership (TPP).

A forma como a demanda crescente por produtos médicos será suprida está diretamente vinculada ao próprio padrão de desenvolvimento e inserção internacional que o Brasil pretende, como potência regional e como membro de uma coligação de potências em nível global (Brics).

A opção do Brasil por uma indústria de saúde (CEIS) robusta e articulada, capaz de atender à sua população em todo o território, de forma autônoma, e impulsionar reformas nas regras e instituições do sistema internacional, colocará o país cada vez mais em conflito com os interesses das grandes empresas transnacionais e das grandes potências, não só no seu próprio mercado, mas também no seu entorno estratégico.

Argumentamos aqui em favor de uma política macroeconômica voltada para o desenvolvimento e o financiamento da área de saúde, nos termos da Constituição Federal, destacando o papel de compra do Estado e as parcerias com o setor privado e empresas estrangeiras. Uma estratégia liderada pelo Estado é condição necessária, mas não suficiente. É preciso que este implemente políticas e arranjos institucionais eficientes e identifique e direcione políticas claras e coesas para os nichos estratégicos de atuação.

A indústria farmacêutica brasileira, baseada na produção de genéricos e similares, percorreu uma trajetória de forte crescimento de 2004 a 2014, associado a um aumento do desequilíbrio e da vulnerabilidade externa brasileira, e se mostra cada vez mais dependente da produção e da tecnologia estrangeiras para atender a suas necessidades. Assim, esse modelo parece esgotado, em razão da crescente importância de medicamentos de maior valor unitário e de maior valor agregado e intensidade tecnológica, bem como da limitação das indústrias do setor no que diz respeito à inovação e ao desenvolvimento de novas moléculas. Esses medicamentos, além de atrair a inserção das grandes empresas globais, têm exercido crescente impacto nas compras do Estado e na balança comercial brasileira. O Brasil faz parte de um grupo de países que conjuga déficit comercial bastante relevante no setor com um volume pouco relevante de exportações.

No Brasil, o significativo déficit comercial no setor Saúde se destaca nos setores de produtos farmoquímicos, medicamentos para uso humano e aparelhos e instrumentos para usos médicos hospitalares. Identifica-se aí uma importante vulnerabilidade comercial e um crescente déficit estrutural, particularmente no setor de farmoquímicos, fármacos e hemoderivados, antibióticos e de insumos farmacêuticos, equipamentos e materiais; neste, inclusive, com risco de extinção de empresas, quadro que se agrava nos produtos com maior intensidade tecnológica.

Aqui identificamos como nichos a biotecnologia e a nanotecnologia, com a produção de insumos, vacinas e antibióticos; o aproveitamento de nossa biodiversidade e o mercado de fitoterápico; a atenção às doenças negligenciadas - não só para o mercado brasileiro; e a produção articulada no setor de máquinas, equipamentos e materiais, no qual as TICs terão papel crescente, e que tem enorme potencial de articulação com a indústria de defesa. 
Sem embargo, a constituição do CEIS com base nos princípios da autonomia estratégica e de segurança em saúde é condição para o Brasil galgar o lugar que lhe cabe no sistema interestatal e atender de forma adequada, invulnerável e soberana, a toda sua população, alcançando os objetivos centrais de segurança e desenvolvimento nacionais. Então, a pergunta central pode ser: que lugar queremos ocupar no mundo cada vez mais competitivo e conflituoso que virá nos próximos anos? No fim, faremos uma escolha: construiremos um modelo capaz de atender a toda a população brasileira ou permitiremos que apenas setores abastados de nossa elite evoluam para o Homo ricus brasiliensis.

\section{Referências}

ACHARYA, S. et al. Brics and global health. Bulletin of the World Health Organization, 92(6): 385-464, 2014. (Special theme: Brics and Global Health)

ADVANCED RESEARCH PROJECTS AGENCY (DARPA). Darpa launches biological technologies office, 1 abr. 2014. Disponível em: <www.darpa.mil/NewsEvents/Releases/2014/04/01.aspx> . Acesso em: 30 jun. 2014.

ALMEIDA, C. Saúde, política externa e cooperação sul-sul em saúde: elementos para reflexão sobre o caso do Brasil. In: GADELHA, P.; CARVALHO, J. N. \& PEREIRA, T. R. (Orgs.). A Saúde no Brasil em 2030: prospeç̧ão estratégica do sistema de saúde brasileiro: desenvolvimento, Estado e políticas de saúde. v. 1. Rio de Janeiro: Fiocruz, Ipea, Ministério da Saúde, Secretaria de Assuntos Estratégicos da Presidência da República, 2013.

ARMITAGE, J. Pfizer drops AstraZeneca takeover BID: American drugs giant admits defeat and scraps offer for British pharmaceutical company. The Independent. London, 26 maio 2014. Disponível em: <www.independent. co.uk/news/business/news/pfizer-admits-defeat-and-drops-astrazeneca-bid-9435767.html>. Acesso em: 26 maio 2014.

ASSOCIAÇÃO BRASILEIRA DA INDÚSTRIA DE ARTIGOS E EQUIPAMENTOS MÉDICOS, ODONTOLÓGICOS, HOSPITALARES E DE LABORATÓRIOS (ABIMO). Dados econômicos. Disponível em <www.abimo.org.br/ modules/content/content.php?page=dados-economicos $>$. Acesso em: 19 set. 2014.

ASSOCIAÇÃO BRASILEIRA DA INDÚSTRIA FARMOQUÍMICA (ABIQUIF). Estatísticas. Disponível em: <www. abiquifi.org.br/mercado_estatisticas.html>. Acesso em: 30 jul. 2014.

BRASIL. Diretrizes de Política Industrial, Tecnológica e de Comércio Exterior, 2003. Disponível em: <www.abdi. com.br/Estudo/Diretrizes_PITCE.pdf>. Acesso em 12 jul. 2014.

BRASIL. Ministério da Defesa. Decreto n. 6.703, de 18 dez. 2008. Aprova a Estratégia Nacional de Defesa, e dá outras providências. Estratégia Nacional de Defesa: paz e segurança para o Brasil. 2. ed. Brasília: Ministério da Defesa, 2008.

BRASIL. Ministério do Desenvolvimento, Indústria e Comércio Exterior. Aliceweb. Disponível em: <http:// aliceweb.mdic.gov.br>. Acesso em: 29 jul. 2014.

BURRILL \& COMPANY. Life Sciences - Capturing Value: healthcare and biogreentech - innovation from discovery. Burrill and Company's 27th Annual Report on the Life Sciences Industry. San Francisco: Burrill Media, 2013.

BUZAN, B. New patterns of global security in the twenty-first century. International Affairs, 67(3): 431-451, 1991.

CHANG, H.-J. Chutando a Escada: a estratégia do desenvolvimento em perspectiva histórica. São Paulo: Editora Unesp, 2002.

CHASE-DUNN, C. Social evolution and the future of world society. Journal of World-System Research, XI: 171192, 2005.

CHASE-DUNN, C.; NIEMEYER, R. \& ALLISON, J. Futures of biotechnology and geopolitics. Irows Working Paper \# 23. Riverside, v. 5-31-06, jun. 2005. 
COPLEY, C. \& SANDLE, P. Novartis and GSK trade assets as pharma industry reshapes. Reuters, 22 abr. 2012. Disponível em: <www.reuters.com/article/2014/04/22/us-novartis-idUSBREA3L07T20140422>. Acesso em: 21 jul. 2014.

DALBY, S. Environmental change. In: WILLIAMS, P. D. (Ed.). Security Studies. London: Routledge, 2008.

DIEGUES, C. Seleção artificial. Piauí. Rio de Janeiro, n. 26, nov. 2008. Disponível em: < http://revistapiaui. estadao.com.br/edicao-26/ficcao/selecao-artificial>. Acesso em: 10 ago. 2014.

ESCOBAR, P. China pivot fuels Eurasian century. On line Asia Times, 19 maio 2014. Disponível em: < http:// atimes.com/atimes/China/CHIN-02-190514.html>. Acesso em: 19 maio 2014.

FIORI, J. L. Ontem, hoje e 2030: tendências do sistema mundial, com ênfase na América do Sul. In: GADELHA, P.; CARVALHO, J. N. \& PEREIRA, T. R. (Orgs.). A Saúde no Brasil em 2030: prospecção estratégica do sistema de saúde brasileiro: desenvolvimento, Estado e políticas de saúde. v. 1. Rio de Janeiro: Fiocruz, Ipea, Ministério da Saúde, Secretaria de Assuntos Estratégicos da Presidência da República, 2013.

FIORI, J. L.; PADULA, R. \& VATER, M. C. A projeção do Brasil na América do Sul e na África Subsaariana e o controle da Bacia do Atlântico Sul. In: CENTRO DE GESTÃO E ESTUDOS ESTRATÉGICOS (CGEE). Dimensões Estratégicas do Desenvolvimento Brasileiro: Brasil, América Latina e África: convergências, geopolítica e estratégias de integração. v. 3. Brasília: CGEE, 2013.

FREEMAN, C. The "National Innovation System" in historical perspective. Cambridge Journal of Economics, 19(1): 5-24, 1995.

FUKUYAMA, F. O Fim da História e o Último Homem. Rio de Janeiro: Rocco, 1992.

GADELHA, C. A. G. \& COSTA, L. S. A saúde na política nacional de desenvolvimento: um novo olhar sobre os desafios da saúde. In: GADELHA, P.; CARVALHO, J. N. \& PEREIRA, T. R. (Orgs.). A Saúde no Brasil em 2030: prospecção estratégica do sistema de saúde brasileiro: desenvolvimento, Estado e políticas de saúde. v. 1. Rio de Janeiro: Fiocruz, Ipea, Ministério da Saúde, Secretaria de Assuntos Estratégicos da Presidência da República, 2013a.

GADELHA, C. A. G. \& COSTA, L. S. A dinâmica de inovação e a perspectiva do CEIS para a sustentabilidade estrutural do sistema de saúde brasileiro. In: GADELHA, P.; CARVALHO, J. N. \& PEREIRA, T. R. (Orgs.). A Saúde no Brasil em 2030: prospecção estratégica do sistema de saúde brasileiro: desenvolvimento, Estado e políticas de saúde. v. 5. Rio de Janeiro: Fiocruz, Ipea, Ministério da Saúde, Secretaria de Assuntos Estratégicos da Presidência da República, 2013b.

GARRET, L. Biology's brave new world: the promise and perils of the synbio revolution. Foreign Affairs, 92(6), 2013. Disponível em: <www.foreignaffairs.com/articles/140156/laurie-garrett/biologys-brave-new-world> . Acesso em: 19 ago. 2014.

GILPIN, R. Global Political Economy: understanding the international economic order. Princeton: Princeton University Press, 2001.

GOMES, R. et al. O novo cenário de concorrência na indústria farmacêutica brasileira. BNDES Setorial, 39: 97-134, 2014.

GUIMARÃES, R. Os dilemas da big pharma. Facto Abifina. Rio de Janeiro, n. 40, abr.-maio-jun. 2014.

GUIMARÃES, S. P. Desafios Brasileiros na Era dos Gigantes. Rio de Janeiro: Contraponto, 2005.

HOMEDICAL. El ganador del Premio Nobel de Medicina Richard J. Roberts denuncia la forma en la que operan las grandes farmacéuticas dentro del sistema capitalista, 13 jun. 2012. Disponível em: <www.homedical.es/ el-ganador-del-premio-nobel-de-medicina-richard-j-roberts-denuncia-la-forma-en-la-que-operan-las-grandesfarmaceuticas-dentro-del-sistema-capitalista>. Acesso em: 2 jul. 2014.

IBAC BRASIL. Brasil fecha parcerias para aumento da produção de biotecnológicos, 25 jun. 2013. Disponível em: <www.ibacbrasil.com/noticias/enfermagem/brasil-fecha-parcerias-para-aumento-da-producao-debiotecnologicos\#sthash.aNJkAuaQ.dpuf>. Acesso em: 23 ago. 2014. 
IMS HEALTH. IMS Health Market Prognosis. Disponível em: <www.imshealth.com:90/files/web/Global/ Market\%20Insights/Market_Prognosis_the_authority_link.pdf>. Acesso em: 20 jun. 2013.

INSTITUTO BRASILEIRO DE GEOGRAFIA E ESTATÍSTICA (IBGE). Conta-Satélite de Saúde Brasil 2007-2009. Contas Nacionais n. 37. Rio de Janeiro: IBGE, Mpog, 2012.

INTERNATIONAL FEDERATION OF PHARMACEUTICAL MANUFACTURERS \& ASSOCIATIONS (IFPMA). The Pharmaceutical Industry and Global Health: facts and figures 2012. Geneva: IFPMA, 2013.

KLARE, M. Rising Powers, Shrinking Planet: how scarce energy is creating a new world order. Oxford: Oneworld Publications, 2008.

KRASNER, S. D. Structural Conflict: the third world against global liberalism. Berkeley and Los Angeles: University of California Press, 1985.

KRASNER, S. D. Power, the State and Sovereignty: essays on international relations. Oxfordshire: Routledge, 2009.

LETTER FROM 10 representatives asking for a meeting to discuss IP policies that could undermine public health and access to medicines, 3 ago. 2011. Disponível em <http://infojustice.org/wp-content/uploads/2011/08/ Ten-Representatives-on-TPP-08022011.pdf> . Acesso em: 20 dez. 2013.

LETTER FROM REPRESENTATIVES Levin, Waxman, McDermott, and Conyers to US Trade Representative Ron Kirk, 19 out. 2011. Disponível em <http://infojustice.org/wp-content/uploads/2011/09/Four-DemocratReps-10192011.pdf>. Acesso em: 10 jan. 2014.

LETTER FROM REPS. Lewis, Stark, Rangel, Blumenauer, and Doggett asking that the May $10^{\text {th }}$ agreement serve as a "non-negotiable starting point" for access to medicines. 8 set. 2011. Disponível em <http://infojustice.org/ wp-content/uploads/2011/09/Five-MOCs-September-8-2011.pdf>. Acesso em: 10 jan. 2014.

LETTER FROM SENATOR Sanders to US Trade Representative Ron Kirk, 1 dec. 2011. Disponível em <http:// keionline.org/sites/default/files/Sen_Sanders_letter_to_USTR_TPP_negotiations_12-1-2011.pdf $>$. Acesso em: 15 abr. 2014.

MAIORES empresas do Brasil em 2013. Exame.com. São Paulo. Disponível em: < http://exame.abril.com.br/ negocios/melhores-e-maiores/empresas/maiores/1/2013/vendas/-/farmaceutico/-/->. Acesso em: 23 jun. 2014.

MCINNES, C. Health. In: WILLIAMS, P. D. (Ed.). Security Studies, an Introduction. London: Routledge, 2008.

MEDEIROS, C. A. O desenvolvimento tecnológico americano no pós-guerra como um empreendimento militar. In: FIORI, J. L. (Org.). O Poder Americano. Petrópolis: Vozes, 2004.

MEDEIROS, C. A. \& TREBAT, N. Military modernization in Chinese technical progress and industrial innovation. In: WORLD KEYNES CONFERENCE, 26-29 jun. 2013, Izmir.

PADULA, R. Integração Regional de Infraestrutura e Comércio na América do Sul nos anos 2000: uma análise político-estratégica, 2010. Tese de Doutorado em Engenharia de Produção, Rio de Janeiro: Instituto Alberto Luiz Coimbra de Pós-Graduação e Pesquisa de Engenharia, Universidade Federal do Rio de Janeiro.

PADULA, R. As visões dominantes sobre a integração regional. In: COSTA, D. (Org.). América do Sul: integração e infraestrutura. Rio de Janeiro: Capax Dei, 2011.

PADULA, R. A geopolítica da Bacia do Pacífico e a integração regional na América do Sul. Revista do Imea-Unila, 1(2): 30-47, 2013.

PADULA, R. A cooperação em saúde no Brics. In: COSTA, D. \& GONÇALVES, W. (Orgs.). O Brasil nos Brics. Rio de Janeiro: Capax Dei, 2015.

PHILLIPS, L. The political economy of ebola. Jacobin. New York, 13 ago. 2014. Disponível em <www.jacobinmag. com/2014/08/the-political-economy-of-ebola/ > . Acesso em: 19 ago. 2014. 
QUENTAL, C. et al. Medicamentos genéricos no Brasil: impactos das políticas públicas sobre a indústria nacional. Ciência \& Saúde Coletiva, 13, supl.: 618-629, 2008. Disponível em: <www.scielo.br/scielo.php?script=sci arttext\&pid=S1413-81232008000700011\&lng=en\&nrm=iso > . Acesso em: 30 ago. 2014 .

QUENTAL, C. et al. Infraestrutura científica e tecnológica para apoio ao CEIS: segmento biofarmacêutico. In: GADELHA, P.; CARVALHO, J. N. \& PEREIRA, T. R. (Orgs.). A Saúde no Brasil em 2030: prospecção estratégica do sistema de saúde brasileiro: desenvolvimento, Estado e políticas de saúde. v. 5. Rio de Janeiro: Fiocruz, Ipea, Ministério da Saúde, Secretaria de Assuntos Estratégicos da Presidência da República, 2013.

REIS, C.; LANDIN, A. \& PIERONI, J. P. Lições da experiência internacional e propostas para incorporação da rota biotecnológica na indústria farmacêutica brasileira. BNDES Setorial, 34: 5-44, 2011.

REIS, R. \& FARIA, J. E. P. Apreensões de medicamentos genéricos e a condenação da UE no Tribunal Permanente dos Povos. Pontes, 6(5), 22 dez. 2010. Disponível em: <www.ictsd.org/bridges-news/pontes/news/apreensõesde-medicamentos-genéricos-e-a-condenação-da-ue-no-tribunal>. Acesso em: 25 jun. 2014.

REIS, R. G. G. Atlântico Sul: um desafio para o século XXI - as velhas ameaças se perpetuam nas novas? In: ACIOLY, L. \& MORAES, R. F. (Orgs.). Prospectiva, Estratégias e Cenários Globais: visões de Atlântico Sul, África Lusófona, América do Sul e Amazônia. Brasília: Ipea, 2011.

RENNSTICH, J. K. The future of great power rivalries. In: DUNAWAY, W. (Ed.). New Theoretical Directions for the $21^{\text {st }}$ Century World-System. New York: Greenwood Press, 2001.

RENNSTICH, J. K. The phoenix cycle: global leadership transition in a long-wave perspective. In: REIFER, T. E. (Ed.). Globalization, Hegemony \& Power: antisystemic movements and the global system. Boulder: Paradigm Publishers, 2004.

SEN, A. Desenvolvimento como Liberdade. São Paulo: Companhia das Letras, 2000.

SILVA, J. B. et al. BRICS cooperation in strategic health projects. Bulletin of the World Health Organization, 92(6): 385-464, 2014. Special theme: BRICS and global health.

SINDICATO DA INDÚSTRIA DE PRODUTOS FARMACÊUTICOS NO ESTADO DE SÃO PAULO (SINDUSFARMA). Gerência de Economia. Indicadores Econômicos. Disponível em: < http://sindusfarma.org.br/cadastro/index. php/site/ap_indicadores>. Acesso em: 25 jul. 2014.

SMITH, M. R. (Ed.). Military Enterprise and Technological Change. Cambridge: MIT Press, 1985.

SPYKMAN, N. Estados Unidos Frente al Mundo. México: Fondo de Cultura, 1942.

THOMAS, C. Poverty. In: WILLIAMS, P. D. (Ed.). Security Studies, an Introduction. London: Routledge, 2008.

UNITED NATIONS CONFERENCE ON TRADE AND DEVELOPMENT (UNCTAD). Trade and Development Report. New York: United Nations, 2007.

UNITED STATES TRADE REPRESENTATIVE (USTR). The United States in the Trans-Pacific partnership, 2011. Disponível em: <www.ustr.gov/about-us/press-office/fact-sheets/2011/november/united-states-trans-pacificpartnership>. Acesso em: 31 jul. 2014.

VARGAS M. A. et al. Indústrias de base química e a biotecnologia voltadas para a saúde no Brasil: panorama atual e perspectivas para 2030. In: GADELHA, P.; CARVALHO, J. N. \& PEREIRA, T. R. (Orgs.). A Saúde no Brasil em 2030: prospecção estratégica do sistema de saúde brasileiro: desenvolvimento, Estado e políticas de saúde. v. 5. Rio de Janeiro: Fiocruz, Ipea, Ministério da Saúde, Secretaria de Assuntos Estratégicos da Presidência da República, 2013.

VEBLEN, T. The Engineers and the Price System. Kitchener: Batoche Books, 2001. Disponível em: <http://socserv2. mcmaster.ca/ econ/ugcm/3ll3/veblen/Engineers.pdf"http://socserv2.mcmaster.ca/ econ/ugcm/3ll3/veblen/ Engineers.pdf > . Acesso em: 31 jul. 2014. 